\title{
Seasonal variations in the highly time-resolved aerosol composition, sources and chemical processes of background submicron particles in the North China Plain
}

\author{
Jiayun $\mathrm{Li}^{1,4,}$, Liming $\mathrm{Cao}^{2} \star$, Wenkang Gao ${ }^{1}$, Lingyan $\mathrm{He}^{2}$, Yingchao Yan ${ }^{1,4}$, Yuexin $\mathrm{He}^{1}$, Yuepeng Pan ${ }^{1}$, \\ Dongsheng $\mathbf{J i}^{1}$, Zirui Liu ${ }^{1,3,4}$, and Yuesi Wang ${ }^{1,3,4}$ \\ ${ }^{1}$ State Key Laboratory of Atmospheric Boundary Layer Physics and Atmospheric Chemistry (LAPC), Institute of \\ Atmospheric Physics, Chinese Academy of Sciences, Beijing 100029, China \\ ${ }^{2}$ Key Laboratory for Urban Habitat Environmental Science and Technology, School of Environment and Energy, Peking \\ University Shenzhen Graduate School, Shenzhen 518055, China \\ ${ }^{3}$ Center for Excellence in Regional Atmospheric Environment, Institute of Urban Environment, Chinese Academy of \\ Sciences, Xiamen 361021, China \\ ${ }^{4}$ College of Earth and Planetary Sciences, University of Chinese Academy of Sciences, Beijing 100049, China \\ ฟ These authors contributed equally to this work.
}

Correspondence: Zirui Liu (liuzirui@mail.iap.ac.cn) and Lingyan He (hely@pkusz.edu.cn)

Received: 4 March 2020 - Discussion started: 18 May 2020

Revised: 11 January 2021 - Accepted: 28 January 2021 - Published: 24 March 2021

\begin{abstract}
For the first time in the North China Plain (NCP) region, we investigated the seasonal variations in submicron particles (NR-PM $)_{1}$ and their chemical composition at a background mountainous site of Xinglong using an Aerodyne high-resolution time-of-flight aerosol mass spectrometer. The average concentration of NR-PM 1 was highest in autumn $\left(15.1 \mathrm{\mu g} \mathrm{m}^{-3}\right)$ and lowest in summer $\left(12.4 \mu \mathrm{g} \mathrm{m}^{-3}\right)$, with a greater abundance of nitrate in spring $(34 \%)$, winter $(31 \%)$ and autumn $(34 \%)$ and elevated organics $(40 \%)$ and sulfate $(38 \%)$ in summer. $\mathrm{PM}_{1}$ in Xinglong showed higher acidity in summer and moderate acidity in spring, autumn and winter, with average $\mathrm{pH}$ values of $2.7 \pm 0.6,4.2 \pm 0.7$, $3.5 \pm 0.5$ and $3.7 \pm 0.6$, respectively, which is higher than those estimated in the United States and Europe. The size distribution of all $\mathrm{PM}_{1}$ species showed a consistent accumulation mode peaking at approximately $600-800 \mathrm{~nm}\left(d_{\mathrm{va}}\right)$, indicating a highly aged and internally mixed nature of the background aerosols, which was further supported by the source appointment results using positive matrix factorization and multilinear engine analysis. Significant contributions of aged secondary organic aerosol (SOA) in organic aerosol (OA) were resolved in all seasons (>77\%), especially in summer. The oxidation state and the process of
\end{abstract}

evolution of OAs in the four seasons were further investigated, and an enhanced carbon oxidation state $(-0.45-0.10)$ and $\mathrm{O} / \mathrm{C}(0.54-0.75)$ and $\mathrm{OM} / \mathrm{OC}(1.86-2.13)$ ratios - compared with urban studies - were observed, with the highest oxidation state appearing in summer, likely because of the relatively stronger photochemical processing that dominated the formation processes of both less oxidized OA (LOOOA) and more oxidized OA (MO-OOA). Aqueous-phase processing also contributed to the SOA formation and prevailed in winter, with the share to MO-OOA being more important than that to LO-OOA. In addition, regional transport also played an important role in the variations in SOA. Especially in summer, continuous increases in SOA concentration as a function of odd oxygen $\left(\mathrm{O}_{x}=\mathrm{O}_{3}+\mathrm{NO}_{2}\right)$ were found to be associated with the increases in wind speed. Furthermore, backward trajectory analysis showed that higher concentrations of submicron particles were associated with air masses transported short distances from the southern regions in all four seasons, while long-range transport from Inner Mongolia (western and northern regions) also contributed to summertime particulate pollution in the background areas of the NCP. Our results illustrate that the background particles in the NCP are influenced significantly by aging processes and 
regional transport, and the increased contribution of aerosol nitrate highlights how regional reductions in nitrogen oxide emissions are critical for remedying occurrence of nitratedominated haze events over the NCP.

\section{Introduction}

With rapid industrialization, population expansion and urbanization, the North China Plain (NCP) has been seriously polluted in recent years (Tao et al., 2012; Du et al., 2015; Yuan et al., 2015; Zhao et al., 2019). The formation mechanisms of particulate pollution are complex because of the unfavorable meteorological conditions, complex source emissions, and geographical conditions. For example, sulfate dominates the secondary inorganic aerosols (SIAs) in heavyindustry cities such as Shijiazhuang and Handan, while in recent years nitrate has dominated those in Beijing because of the strict emissions reduction measures for coal combustion (Huang et al., 2019; Li et al., 2019a; Duan et al., 2019). High relative humidity $(\mathrm{RH})$ favors heterogeneous reactions and hygroscopic growth, leading to an increase in secondary aerosols and further aggravating haze pollution over the NCP (Sun et al., 2013a; Liu et al., 2016). Moreover, haze pollution over the NCP can be exacerbated by its unique topography. Hu et al. (2014) found that heat from the Loess Plateau can be transported to the plain with westerly airflow, resulting in enhanced thermal inversion and suppression of the planetary boundary layer (PBL), thus weakening atmospheric diffusion. Furthermore, the southern NCP is an important pathway for water vapor and pollutant transport in the PBL because of the blocking effect of the Taihang Mountains (Tao et al., 2012).

Nearly all previous research on the characterization of fine particles over the NCP has been conducted at heavily polluted urban or suburban stations with strong local source emissions, with a few studies having been deployed at background stations. Early studies found that secondary aerosols dominate the aerosol particles at background sites, and regional transport affects the air pollution of the background atmosphere (Pan et al., 2013; Liu et al., 2018; Huang et al., 2017). However, these studies at background sites in the NCP were limited by a low temporal resolution of 1 or several days. High-resolution time-of-flight aerosol mass spectrometry (HR-ToF-AMS) has been widely used to characterize nonrefractory submicron particles $\left(\mathrm{NR}-\mathrm{PM}_{1}\right)$ at numerous urban sites. However, the high-time-resolution studies at background sites in the NCP by HR-ToF-AMS instrument are still limited. Zhang et al. (2017) investigated the NR-PM species in 2015 at a background site (Shangdianzi) by a HRToF-AMS instrument and Li et al. (2019b) conducted the observation in winter 2018 at a background site (Xinglong) by a Quadrupole AMS (Q-AMS) in the NCP. Both studies showed the dominant role of organics and nitrate, and organics were highly oxidized in the background atmosphere in the NCP. However, both of the studies were concentrated in wintertime, and the compositions of $\mathrm{PM}_{1}$, the sources and oxidation state of organic aerosol (OA) changed significantly in different background sites and seasons. For example, nitrate and $\mathrm{OA}$ dominated $\mathrm{PM}_{1}$ in autumn and winter at the Xinglong and Mt. Waliguan sites in the NCP and in spring at Mount Wuzhi site in northern China (Zhu et al., 2016), while sulfate and $\mathrm{OA}$ dominated $\mathrm{PM}_{1}$ in summer at the Waliguan site in western China (Zhang et al., 2019) and in spring at the Lake Hongze site in southern China (Zhu et al., 2016). Organics were highly oxidized at these background sites, while the oxidation state of organics in southern China was higher than that in northern China (Zhu et al., 2016). Hydrocarbonlike OA (HOA) accounted for $30 \%$ in OA in spring at Mount Wuzhi in northern China. Biomass burning OA and aged biomass burning OA accounted for $18 \%$ and $40 \%$ in OA in summer, respectively, while HOA only accounted for $6 \%$, in western China (Zhang et al., 2019). No primary organic sources were found in southern China in spring (Zhu et al., 2016). These substantial differences highlighted the importance of long-term observations for understanding the seasonal characteristics of aerosol species and sources in the background atmosphere. What's more, pollutants in the background areas are frequently influenced by the regional transport from the urban areas, highlighting the importance of the seasonal variations in the impacts of regional transport on aerosol mass loadings and chemistry at background sites. However, no systematic measurements with high time resolution of the mass-size distributions of chemical components in fine aerosol particles, covering four seasons, have yet been reported in the background atmosphere in the NCP, which would hinder our understanding on the evolution and chemical processes of secondary aerosol and regional transport on a regional scale. Only one study investigated the seasonal variations in $\mathrm{PM}_{1}$ species at a background site in central east China at Mount Tai (Zhang et al., 2014b) based on unit mass resolution (UMR). The study only presented the characterization of the total OA; the sources of OA were not identified. Furthermore, there was no elemental information, which can determine the oxidation state of OA and characterize the evolution and processes of secondary organic aerosol (SOA). Actually, the evolution and formation mechanisms of SOA in the background atmosphere are still unclear. Currently, research focusing on this field tends to be concentrated in urban areas, and the results vary in different places and seasons. For example, photochemical processing was found to dominate the oxidation state of OA in haze events, whereas aqueous-phase processing was the main reason during foggy events in Hong Kong (Li et al., 2013; Qin et al., 2016). In urban Beijing, Xu et al. (2017) found that aqueous-phase processing dominated MO-OOA (more oxidized OA) formation in all seasons. Meanwhile, more recently, Li et al. (2020) found that the impact of photochemistry on MO-OOA formation enhanced as the photochemical age increased in early 
autumn in Beijing. Due to the stronger atmospheric oxidizing capacity and higher oxidation state of organics in the background atmosphere than in the urban atmosphere over the NCP, the evolution and formation mechanisms of SOA would be largely different from those of urban areas, mainly due to the complex interactions of local emissions, chemical reactions and meteorological influences. Conversely, these kinds of studies were still limited and hinder our understanding of background aerosol chemistry in polluted regions such as the NCP. Therefore, we present 1 year of measurements of submicron aerosols at a regional background station in NCP, to explore the seasonal variations in aerosol sources and formation processes. In particular, the influence of photochemical and aqueous-phase processing on SOA production (LO-OOA (less oxidized OA) and MO-OOA) was evaluated based on robust data analyses.

In this study, an HR-ToF-AMS instrument was first deployed with instruments for the measurement of meteorological parameters and gaseous parameters during all four seasons at the Xinglong background station to investigate the seasonal variations in $\mathrm{PM}_{1}$ species in the background atmosphere of the NCP. The seasonal variations in the submicron aerosols, including the variation in mass concentration, chemical composition, aerosol acidity, size distribution, diurnal variation and meteorological effects, are presented in detail in this paper. The seasonal sources, oxidation state and evolutionary processes of LO- and MO-OOA production are fully explored. Finally, backward trajectory analyses were performed to investigate the different pathways and the regional transport influences on the background atmospheric aerosols during the four seasons over the NCP.

\section{Experimental methods}

\subsection{Sampling sites}

The Xinglong background station is located in the north of Hebei Province, south of the Yan Mountains, $960 \mathrm{~m}$ above sea level, at a longitude and latitude of 117.67 and $40.40^{\circ}$, respectively, about $115 \mathrm{~km}$ northeast of Beijing (Pan et al., 2013). Since Xinglong station is surrounded by forests and there are no serious pollutant emissions in this area, it can be considered an ideal station to investigate haze episodes over the NCP on a regional scale. More details about Xinglong station can be found in $\mathrm{Li}$ et al. (2019b) and Tian et al. (2018).

\subsection{Instrumentation and operation}

From March to December 2019, an HR-ToF-AMS was deployed to measure the mass concentrations and chemical compositions of NR-PM $\mathrm{PM}_{1}$. The sampling periods were from 1 to 31 May, 20 June to 26 July, 12 October to 12 November, and 25 November to 25 December 2019. The ambient particles were sampled into the AMS through a URG cyclone
(URG-2000-30ED) for removing coarse particles with size cutoffs of $2.5 \mu \mathrm{m}$, which was followed by use of a Nafion dryer to dry the sampled aerosols to eliminate the impact of high humidity on particles. During these four campaigns, both the "V" and "W" modes were operated, and the temporal resolution was 3 min. Under V-mode operation, the AMS cycled through the mass spectrum (MS) mode and the particle time-of-flight (PToF) mode every $30 \mathrm{~s}$, spending 10 and $20 \mathrm{~s}$ in each mode, respectively. The HR-ToF-AMS calibrations were carried out strictly according to the standards reported in previous studies (Jimenez et al., 2003; Zhang et al., 2014a).

Simultaneously, other measurements were also deployed during the whole campaign. Specifically, a Sharp-5030 instrument was used to measure the total $\mathrm{PM}_{1}$ concentration. Gaseous species, including ozone $\left(\mathrm{O}_{3}\right)$, nitric oxide $(\mathrm{NO})$, nitrogen dioxide $\left(\mathrm{NO}_{2}\right)$, carbon monoxide $(\mathrm{CO})$ and sulfur dioxide $\left(\mathrm{SO}_{2}\right)$, were measured using Thermo gas analyzers. A Milos520 (Vaisala, Finland) was used to obtain the meteorological parameters. An ammonia $\left(\mathrm{NH}_{3}\right)$ analyzer $\left(\mathrm{NH}_{3}-\mathrm{H}_{2} \mathrm{O}\right.$, model 911-0016, Los Gatos Research) was also used to simultaneously measure related gases. More details about the instruments can be seen in Li et al. (2019b).

\subsection{Data analysis}

The analysis software programs known as SQUIRREL $(\mathrm{v} 1.57 \mathrm{H})$ and PIKA (v1.16H) were used to analyze the size-resolved mass concentrations and mass spectra of OA, respectively. According to Canagaratna et al. (2015), the improved-ambient method was used to obtain the elemental composition ratios. In this study, the relative ionization efficiency (RIE) values used were 1.1, 1.2, 1.3 and 1.4 for nitrate, sulfate, chloride and organics, respectively. An RIE value of 4.0 was used for ammonium based on the ionization efficiency calibration results in each season. The particle collection efficiency (CE) was applied to account for the incomplete detection of particles due to particle bounce (Aiken et al., 2009). According to Middlebrook et al. (2012), the CE value can be affected by the RH, aerosol acidity and ammonium nitrate mass fractions (ANMFs). The ambient aerosols were dried using a Nafion dryer. Meanwhile, aerosols were neutral in spring, autumn and winter and weakly acidic in summer (Fig. 2). Therefore, RH and aerosol acidity could not influence the CE values in all seasons. However, the ANMF values were mostly above 0.4 in spring, autumn and winter, indicating that $\mathrm{NH}_{4} \mathrm{NO}_{3}$ would substantially affect the CE values in these three seasons. Through the combined analysis of the above three aspects, a constant CE of 0.5 was used in summer, and the CE values in the other three seasons were calculated according to Middlebrook et al. (2012) $[\mathrm{CE}=\max (0.45,0.0833+0.9167 \times \mathrm{ANMF})]$.

The positive matrix factorization (PMF) Evaluation Tool PET (v3.04A; Ulbrich et al., 2009; Zhang et al., 2011) was employed for the OA source apportionment in each season. 
The error matrix was modified; ions with low signal-to-noise ratios were down-weighted or removed. It is common to use PMF analysis to identify the sources of OA. However, it is difficult to distinguish similar factors in areas with complex pollution sources. Owing to the high fraction of OOA in OA, it is extremely difficult to separate primary OA (POA) from oxygenated OA (OOA) in Xinglong using PMF analysis, because the POA factor is easily mixed with the OOA factor. Therefore, the multilinear engine (ME-2) analysis was also used to separate POA from OOA in spring and autumn. The $a$ value of $0-0.5$ with a space of 0.1 in each season was used to constrain the POA profiles to explore the solution space (Canonaco et al., 2013). As a result, fossil fuel OA (FFOA), LO-OOA and MO-OOA, were identified with ME-2 analysis in spring and autumn. In winter, the PMF analysis results of two OA factors (LO-OOA and MO-OOA) were used. Details of the diagnosis information can be seen in Sect. 3.2 and in the Supplement (Figs. S2-S20, Tables S1 and S2).

\subsection{Backward trajectory modeling}

The $48 \mathrm{~h}$ back trajectories were calculated every hour at a height of $200 \mathrm{~m}$ (above ground level) using the HYSPLIT (Hybrid Single-Particle Lagrangian Integrated Trajectories) model, version 4.8, in each season. Meteorological data archived by the Air Resource Laboratory, NOAA, were used, the resolution of which was $1^{\circ} \times 1^{\circ}$. The cluster analysis algorithm was used to classify the back trajectories of each season.

\subsection{Aerosol acidity estimation}

Aerosol $\mathrm{pH}$ was predicted using the aerosol thermodynamic model ISORROPIA II, according to the equation as follows (Guo et al., 2015, 2017):

$\mathrm{pH}=-\log _{10} H_{\mathrm{aq}}^{+}=-\log _{10} \frac{1000 H_{\mathrm{air}}^{+}}{W_{\mathrm{i}}+W_{\mathrm{o}}}$,

where $H_{\text {air }}^{+}$is the $\mathrm{H}^{+}$concentration per volume of air and can be obtained from the ISORROPIA II model. $W_{\mathrm{i}}$ and $W_{\mathrm{o}}$ are the liquid water content (LWC) of inorganic and organic components, respectively. $W_{\mathrm{i}}$ and $H_{\text {air }}^{+}$can be obtained by the ISORROPIA II model. A previous study in northern China showed that organic particle in water accounts for only $5 \%$ of the total LWC (Liu et al., 2017), so $W_{\mathrm{o}}$ was not calculated in this study. The forward mode was used with just aerosol-phase data and $\mathrm{NH}_{3}$ data input in this study, to avoid measurement error (Song et al., 2019; Guo et al., 2017). Notably, data for $\mathrm{RH}<30 \%$ and $\mathrm{RH}>95 \%$ were excluded because of the large uncertainty in LWC and $\mathrm{pH}$ values (Ding et al., 2019; Guo et al., 2015).

\section{Results and discussion}

\subsection{Mass concentrations of $\mathrm{PM}_{1}$ species}

\subsubsection{Seasonality of the chemical composition of $\mathrm{PM}_{1}$}

The annual mean mass concentrations of organics, nitrate, sulfate, ammonium and chloride in $\mathrm{PM}_{1}$ were $4.6 \pm 3.8$, $3.7 \pm 5.7,3.2 \pm 3.3,2.0 \pm 2.3$ and $0.1 \pm 0.1 \mu^{-3} \mathrm{~m}^{-3}$, respectively, totaling $12.9 \pm 14.1 \mu^{-3} \mathrm{~m}^{-3}$. This total $\mathrm{PM}_{1}$ concentration was much lower than the values observed in urban and suburban areas in the NCP, such as $81 \mu \mathrm{g} \mathrm{m}^{-3}$ in urban Beijing (Hu et al., 2017), $187 \mu \mathrm{g} \mathrm{m}^{-3}$ in urban Handan and $178 \mu \mathrm{g} \mathrm{m}^{-3}$ in urban Shijiazhuang in Hebei Province in winter (Li et al., 2017; Huang et al., 2019) and $52 \mu \mathrm{g} \mathrm{m}^{-3}$ at the suburban station of Gucheng (Zhang, 2011). However, it was higher than those in national background areas in eastern and western China, such as $9.1 \mathrm{gg} \mathrm{m}^{-3}$ at Waliguan background station in summer, $4.4 \mu \mathrm{g} \mathrm{m}^{-3}$ at the southern edge of the Tibetan Plateau in spring and $10.9 \mu \mathrm{g} \mathrm{m}^{-3}$ at Mount Wuzhi station in spring (Zhang et al., 2019; Zhu et al., 2016). The higher $\mathrm{PM}_{1}$ mass concentration at Xinglong in the background atmosphere of the NCP compared to those in other remote areas in eastern and western China indicated the air pollution over the NCP is serious.

Seasonally, the average $\mathrm{PM}_{1}$ concentrations were $13.7 \pm$ $16.0,12.4 \pm 7.4,15.1 \pm 18.7$ and $14.1 \pm 13.34{\mu g^{-3}}^{-3}$ in the four seasons, respectively. OA showed the highest portion in NR-PM 1 in summer, accounting for $40 \%$ by mass. Nitrate was the highest SIA component in spring (34\%), winter (31\%) and autumn (34\%). The low percentage of nitrate in summer $(9.6 \%)$ might be attributable to the higher temperatures than in other seasons, which suppress the partitioning to particulate nitrate (Seinfeld and Pandis, 2016). Sulfate remained relatively low in spring $(16 \%)$, autumn $(21 \%)$ and winter $(19 \%)$, but it increased to $38 \%$ of the NR-PM 1 mass in summer. Ammonium accounted for $13 \%-17 \%$ of $\mathrm{PM}_{1}$ concentrations in all four seasons.

As shown in Fig. 1, the proportions of $\mathrm{OA}$ in $\mathrm{PM}_{1}$ gradually decreased as $\mathrm{PM}_{1}$ increased in all seasons, suggesting that the enhanced SIA dominated the increase in $\mathrm{PM}_{1}$, similar to the findings in previously reported research $(\mathrm{Hu}$ et al., 2017; Zhang et al., 2019). The proportions of nitrate in $\mathrm{PM}_{1}$ increased slightly in spring, summer and autumn. In comparison, the proportion of nitrate increased first and then decreased with a high $\mathrm{PM}_{1}$ concentration $\left(\mathrm{PM}_{1}>\right.$ $50 \mu \mathrm{g} \mathrm{m}^{-3}$ ) in winter. The difference may be due to the seasonal differences of heterogeneous reactions on nitrate formation. The proportions of ammonium remained stable in all seasons even when the $\mathrm{PM}_{1}$ concentration was low, suggesting that ammonia is excessive over the NCP. Although the average $\mathrm{PM}_{1}$ concentrations in the four seasons were similar (Table 1), the frequency distribution of $\mathrm{PM}_{1}$ (Fig. 1, white curve) showed strong seasonal dependency. High-frequency and extremely low-frequency $\mathrm{PM}_{1}$ concentrations were ob- 
served when the $\mathrm{PM}_{1}$ concentration was below $10 \mu \mathrm{g} \mathrm{m}^{-3}$ and above $40 \mu \mathrm{g} \mathrm{m}^{-3}$, respectively, in spring, autumn and winter. In summer, the frequency distribution of $\mathrm{PM}_{1}$ did not change dramatically as $\mathrm{PM}_{1}$ increased.

\subsubsection{Seasonality of aerosol acidity}

The acidity of $\mathrm{PM}_{1}$ was evaluated in each season using the thermodynamic model ISORROPIA-II (Table 2). $\mathrm{PM}_{1}$ in Xinglong showed moderate acidity in spring, autumn and winter, with average $\mathrm{pH}$ values of $4.2 \pm 0.7,3.5 \pm 0.5$ and $3.7 \pm 0.6$, respectively. Comparatively, the $\mathrm{pH}$ value in summer was the lowest $(2.7 \pm 0.6)$ among all seasons, similar to the findings of previous studies (Ding et al., 2019; Liu et al., 2017). The seasonal variation in the $\mathrm{pH}$ at Xinglong was similar to results reported in urban Beijing, except for spring and winter. The $\mathrm{pH}$ value in urban Beijing was highest in winter, followed by spring ( $4.4 \pm 1.2)$, autumn $(4.3 \pm 0.8)$ and summer (3.8 \pm 1.2 ) (Ding et al., 2019). The seasonal variation in $\mathrm{pH}$ in this study was strongly related to the chemical composition of aerosols in each season. Previous studies show that sulfate can lead to a much higher concentration of $\mathrm{H}_{\text {air }}^{+}$ than nitrate due to its low volatility (Ding et al., 2019; Tan et al., 2018; Xu et al., 2019). In this study, the mass fraction of sulfate in $\mathrm{PM}_{1}$ was highest in summer (37\%) and lowest in spring (16\%). Similarly, the nitrate-to-sulfate ratio was highest in spring (2.13) and lowest in summer (0.26). Recent studies have shown that sulfate has been effectively reduced in Beijing because of the strict emission control measures, and the mass fraction of nitrate in PM has increased significantly, with an increased $\mathrm{NO}_{3} / \mathrm{SO}_{4}$ ratio in Beijing ubiquitously observed (Xu et al., 2019; Song et al., 2019).

Notably, the $\mathrm{pH}$ in spring $(4.2 \pm 0.7)$ was similar to the value found in urban Beijing $(4.4 \pm 1.2)$ in the same season. In comparison, the $\mathrm{pH}$ values in autumn and winter were 0.5 to 1.1 lower than those found in urban areas of northern China, such as $4.3 \pm 0.8$ in autumn in Beijing, 4.5 (3.85.2) in winter in Zhengzhou and 4.8 (3.9-5.9) in winter in Anyang (Ding et al., 2019; Wang et al., 2020). The higher LWC in urban areas may be one of the important reasons for its slightly lower acidity in autumn and winter compared to that in background areas in northern China. Aerosol acidity is closely related to LWC, with higher LWC usually accompanied by higher aerosol $\mathrm{pH}$ according to previous studies (Guo et al., 2015; Liu et al., 2017). In this study, the LWC in autumn and winter was $18 \pm 38$ and $12 \pm 26 \mu \mathrm{g} \mathrm{m}^{-3}$, respectively, which was obviously lower than that in urban areas, such as $109 \pm 160 \mu \mathrm{g} \mathrm{m}^{-3}$ in autumn in Beijing (Ding et al., 2019), 220 (28-711) $\mu \mathrm{g} \mathrm{m}^{-3}$ in winter in Beijing (Liu et al., 2017) and $95 \mu \mathrm{g} \mathrm{m}^{-3}$ in winter in Zhengzhou (Wang et al., 2020). The higher LWC in urban areas is mainly due to the high aerosol concentrations, which can enhance aerosol water uptake (Liu et al., 2017). In comparison, the $H_{\text {air }}^{+}$concentration was $3.7 \mathrm{pg} \mathrm{m}^{-3}$ in autumn and $1.2 \mathrm{pg} \mathrm{m}^{-3}$ in winter, which were comparable with that observed in urban ar- eas. Therefore, the lower $\mathrm{LWC} / H_{\text {air }}^{+}$ratio in Xinglong favored the slightly lower $\mathrm{pH}$ values, according to Eq. (1).

Moreover, the $\mathrm{pH}$ values in this study and previous studies in urban areas of the NCP were 0.8 to 3.5 units higher than those observed in the US and Europe, such as $1.2 \pm 1.1$ in Crete, Greece, in winter (Bougiatioti et al., 2016); $0.9 \pm 0.6$ in Alabama, southeastern US, in summer (Guo et al., 2015); and $2.2 \pm 0.6$ in Yorkville, southeastern US, in autumn (Nah et al., 2018). The excessive $\mathrm{NH}_{3}$ emissions in the NCP play an important role in the large gap (Song et al., 2019). In this study, the average $\mathrm{NH}_{3}$ concentrations were $12,19,8$ and $4 \mathrm{ppb}$ in each season, with a maximum value of $39 \mathrm{ppb}$, while in the southeastern US, $\mathrm{NH}_{3}$ generally ranged between 0.1 and $3.0 \mathrm{ppb}$ (Weber et al., 2016). Another explanation might be the changes in chemical composition of aerosols over the NCP. The $\mathrm{NO}_{3} / \mathrm{SO}_{4}$ ratios in this study and urban areas of the NCP were obviously higher than those in other countries (Table 2). Thus, the relatively lower aerosol acidity in the NCP might be attributable to the excessive $\mathrm{NH}_{3}$ and high $\mathrm{NO}_{3} / \mathrm{SO}_{4}$ ratios on a regional scale in this region.

\subsubsection{Seasonality of meteorological effects on $\mathbf{P M}_{1}$ species}

The chemical composition of $\mathrm{PM}_{1}$ exhibited distinct characteristics in the four seasons, which was due to the significant seasonal variation in meteorological conditions and emissions. As shown in Table $2, \mathrm{NO}_{x}$ exhibited its highest concentration in winter and correlated well with chloride $\left(R^{2}=0.6\right)$, suggesting a strong influence of fossil fuel combustion, such as coal combustion. The enhancement of emission in winter in the NCP led to the increase in $\mathrm{NO}_{x}$ in background atmosphere, which was mainly due to the regional transport. $\mathrm{SO}_{2}$ concentrations were low in all seasons and showed no obvious seasonal changes (1.0-1.9 ppb). The $\mathrm{O}_{3}$ concentration was highest in summer, likely due to the high temperatures and enhanced photochemical processing.

Horizontal wind speed can affect the diffusion and transportation of pollutants. In spring and winter, with the increase in wind speed, the concentrations of almost all $\mathrm{PM}_{1}$ species decreased, suggesting an impact of the dilution of winds on atmospheric aerosols (Fig. 2). However, the wind dilution ratios (percentage decrease in the concentration of the aerosol species for every $1 \mathrm{~m} \mathrm{~s}^{-1}$ decrease in wind speed) were much lower than the observed value in urban Beijing in winter ( $\mathrm{Li}$ et al., 2019b) but comparable to the value observed at a rural station (Wang et al., 2016), suggesting that aerosols in the background atmosphere were homogeneously distributed. Therefore, the winds showed a weaker influence in terms of diluting aerosol particles than the result observed in Beijing. In autumn, $\mathrm{PM}_{1}$ species only decreased rapidly when wind speed was $>4 \mathrm{~m} \mathrm{~s}^{-1}$, while SIAs increased rapidly from 1 to $4 \mathrm{~m} \mathrm{~s}^{-1}$, suggesting a significant role of intermediate wind speed in SIA transport, similar to the findings of a previous study conducted in autumn in 

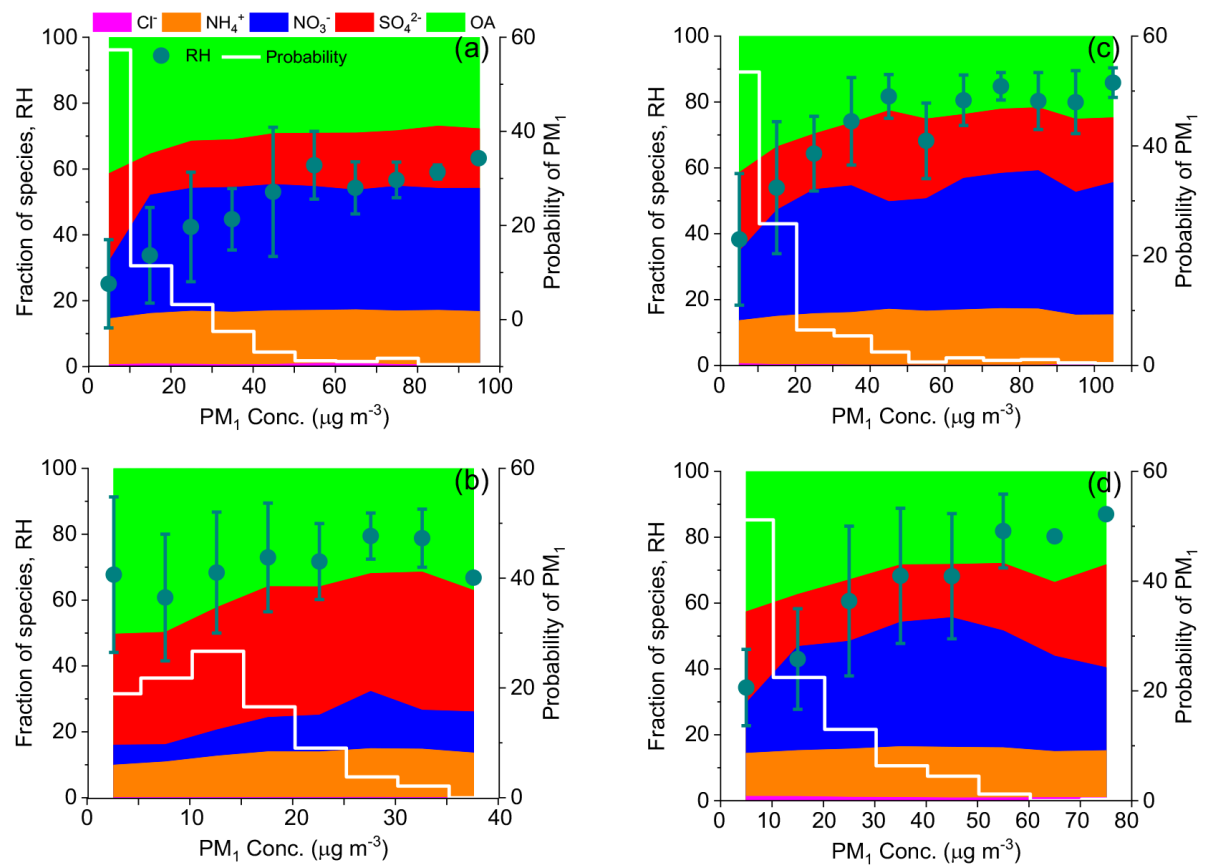

Figure 1. Fractions of $\mathrm{PM}_{1}$ species in $\mathrm{PM}_{1}$ as a function of $\mathrm{PM}_{1}$ concentration and the probability density of $\mathrm{PM}_{1}$ (white curves) in (a) spring, (b) summer, (c) autumn and (d) winter. The average values and standard deviations of RH are illustrated.

Table 1. Seasonal variations in average meteorological parameters, gaseous precursors and NR-PM 1 species. The data here are listed in the form of "average \pm standard deviation".

\begin{tabular}{|c|c|c|c|c|}
\hline & $\begin{array}{r}\text { Spring } \\
1 \text { May-31 March }\end{array}$ & $\begin{array}{r}\text { Summer } \\
\text { 22 June-27 July }\end{array}$ & $\begin{array}{r}\text { Autumn } \\
11 \text { October-11 November }\end{array}$ & $\begin{array}{r}\text { Winter } \\
25 \text { November-26 December }\end{array}$ \\
\hline \multicolumn{5}{|c|}{ Meteorological parameters } \\
\hline$T\left(^{\circ}\right)$ & $3.9 \pm 4.7$ & $21.4 \pm 3.9$ & $8.1 \pm 3.9$ & $-5.1 \pm 3.1$ \\
\hline $\mathrm{RH}(\%)$ & $31 \pm 17$ & $68 \pm 19$ & $49 \pm 23$ & $44 \pm 20$ \\
\hline $\mathrm{WS}\left(\mathrm{m} \mathrm{s}^{-1}\right)$ & $3.3 \pm 1.3$ & $2.0 \pm 1.3$ & $2.1 \pm 1.3$ & $2.4 \pm 1.4$ \\
\hline Pressure $(\mathrm{hPa})$ & $913 \pm 4$ & $906 \pm 3$ & $918 \pm 5$ & $920 \pm 5$ \\
\hline \multicolumn{5}{|c|}{ Gaseous precursors } \\
\hline $\mathrm{O}_{3}(\mathrm{ppb})$ & $48 \pm 11$ & $78 \pm 24$ & $37 \pm 13$ & $29 \pm 8$ \\
\hline $\mathrm{NO}(\mathrm{ppb})$ & $0.2 \pm 0.2$ & $0.2 \pm 0.3$ & $0.4 \pm 0.8$ & $0.7 \pm 1.4$ \\
\hline $\mathrm{NO}_{2}(\mathrm{ppb})$ & $4.0 \pm 4.0$ & $4.0 \pm 2.0$ & $12 \pm 7$ & $14 \pm 10$ \\
\hline $\mathrm{NO}_{x}(\mathrm{ppb})$ & $4.3 \pm 4.1$ & $4.3 \pm 2.2$ & $13 \pm 9$ & $15 \pm 11$ \\
\hline $\mathrm{SO}_{2}(\mathrm{ppb})$ & $1.0 \pm 1.2$ & $1.9 \pm 1.7$ & $1.3 \pm 1.7$ & $0.7 \pm 1.2$ \\
\hline $\mathrm{CO}(\mathrm{ppm})$ & $0.55 \pm 0.41$ & $0.49 \pm 0.25$ & $0.54 \pm 0.22$ & $0.59 \pm 0.33$ \\
\hline \multicolumn{5}{|c|}{ Aerosol species $\left(\mu \mathrm{g} \mathrm{m}^{-3}\right)$} \\
\hline Org & $4.5 \pm 4.7$ & $4.9 \pm 2.6$ & $4.5 \pm 3.6$ & $4.8 \pm 3.8$ \\
\hline FFOA & $0.7 \pm 0.7$ & & $0.6 \pm 0.5$ & $1.1 \pm 0.9$ \\
\hline LO-OOA & $1.2 \pm 1.7$ & $1.9 \pm 1.1$ & $1.3 \pm 0.7$ & $1.2 \pm 1.2$ \\
\hline MO-OOA & $2.8 \pm 2.8$ & $3.0 \pm 1.6$ & $2.7 \pm 2.6$ & $2.3 \pm 2.0$ \\
\hline $\mathrm{SO}_{4}^{2-}$ & $2.2 \pm 2.6$ & $4.6 \pm 3.1$ & $3.1 \pm 4.0$ & $2.7 \pm 2.8$ \\
\hline $\mathrm{NO}_{3}^{-}$ & $4.7 \pm 6.3$ & $1.2 \pm 14$ & $5.1 \pm 7.6$ & $4.4 \pm 5.2$ \\
\hline $\mathrm{NH}_{4}^{+}$ & $2.1 \pm 2.6$ & $1.6 \pm 1.2$ & $2.3 \pm 3.0$ & $2.0 \pm 2.0$ \\
\hline $\mathrm{Cl}^{-}{ }^{4}$ & $0.1 \pm 0.1$ & $0.01 \pm 0.02$ & $0.04 \pm 0.06$ & $0.2 \pm 0.2$ \\
\hline NR-PM 1 & $13.7 \pm 16.0$ & $12.4 \pm 7.4$ & $15.1 \pm 18.7$ & $14.1 \pm 13.3$ \\
\hline
\end{tabular}


Table 2. Mass concentrations of nitrate, sulfate, ammonium, LWC, $H_{\text {air }}^{+}$and $\mathrm{pH}$ values in China and other countries.

\begin{tabular}{|c|c|c|c|c|c|c|c|c|}
\hline Site & Period & $\begin{array}{c}\mathrm{SO}_{4}^{2-} \\
\left(\mu \mathrm{g} \mathrm{m}^{-3}\right)\end{array}$ & $\begin{array}{r}\mathrm{NO}_{3}^{-} \\
\left(\mu \mathrm{g} \mathrm{m}^{-3}\right)\end{array}$ & $\begin{array}{c}\mathrm{NH}_{4}^{+} \\
\left(\mu \mathrm{g} \mathrm{m}^{-3}\right)\end{array}$ & $\begin{array}{r}\text { LWC } \\
\left(\mu \mathrm{g} \mathrm{m}^{-3}\right)\end{array}$ & $\begin{array}{r}H_{\text {air }}^{+} \\
\left(\mathrm{pg} \mathrm{m}^{-3}\right)\end{array}$ & $\mathrm{pH}$ & Reference \\
\hline \multirow[t]{4}{*}{ Xinglong, China } & Spring & $2.2 \pm 2.6$ & $4.7 \pm 6.3$ & $2.1 \pm 2.6$ & $6 \pm 13$ & $0.5 \pm 0.6$ & $4.2 \pm 0.7$ & \multirow[t]{4}{*}{ This study } \\
\hline & Summer & $4.6 \pm 3.1$ & $1.2 \pm 1.4$ & $1.6 \pm 1.2$ & $14 \pm 24$ & $42 \pm 68$ & $2.7 \pm 0.6$ & \\
\hline & Autumn & $3.1 \pm 4.0$ & $5.1 \pm 7.6$ & $2.3 \pm 3.0$ & $18 \pm 38$ & $3.7 \pm 6.9$ & $3.5 \pm 0.5$ & \\
\hline & Winter & $2.7 \pm 2.8$ & $4.4 \pm 5.2$ & $2.0 \pm 2.0$ & $12 \pm 26$ & $1.2 \pm 2.4$ & $3.7 \pm 0.6$ & \\
\hline \multirow[t]{3}{*}{ Beijing, China } & Spring & $8.4 \pm 7.7$ & $12.6 \pm 14.2$ & $6.7 \pm 7.2$ & $21 \pm 33$ & $3.7 \pm 15$ & $4.4 \pm 1.2$ & \multirow[t]{3}{*}{ Ding et al. (2019) } \\
\hline & Summer & $8.6 \pm 7.5$ & $9.5 \pm 9.5$ & $7.2 \pm 5.6$ & $50 \pm 68$ & $16 \pm 18$ & $3.8 \pm 1.2$ & \\
\hline & Autumn & $6.5 \pm 5.9$ & $18.5 \pm 19.5$ & $8.2 \pm 8.2$ & $109 \pm 160$ & $8.1 \pm 11$ & $4.3 \pm 0.8$ & \\
\hline Beijing, China & Winter & & & & $220(28-711)$ & 11.7 & $4.2(3.0-4.9)$ & Liu et al. (2017) \\
\hline Zhengzhou, China & Winter & & & & $95(10-250)$ & 2.0 & $4.5(3.8-5.2)$ & \multirow[t]{2}{*}{ Wang et al. (2020) } \\
\hline Anyang, China & Winter & & & & $70(5-190)$ & 1.0 & $4.8(3.9-5.9)$ & \\
\hline Yorkville, US & Autumn & $1.6 \pm 0.4$ & $0.2 \pm 0.1$ & $0.4 \pm 0.2$ & $1.6 \pm 1.7$ & 10.0 & $2.2 \pm 0.6$ & Nah et al. (2018) \\
\hline Alabama, US & Summer & $1.7 \pm 1.2$ & $0.08 \pm 0.08$ & $0.5 \pm 0.3$ & $5.1 \pm 3.8$ & 1.5 & $0.9 \pm 0.6$ & Guo et al. (2015) \\
\hline Crete, Greece & Autumn & $2.3 \pm 1.6$ & $0.8 \pm 0.6$ & $0.5 \pm 0.2$ & $2.2 \pm 1.7$ & $2-4.5$ & $1.2 \pm 1.1$ & Bougiatioti et al. (2016) \\
\hline
\end{tabular}

Xinglong (Li et al., 2019b). In summer, all $\mathrm{PM}_{1}$ species decreased gradually as the wind speed increased, except OA and sulfate, suggesting a strong influence of regional transport on OA and sulfate formation, especially the former. The relationship between pollutants and wind direction in summer also differed from that in other seasons. All $\mathrm{PM}_{1}$ species showed high concentrations in association with wind from the southern regions and low concentrations in association with wind from the northern regions, in spring, autumn and winter. In summer, $\mathrm{PM}_{1}$ species also showed relatively high concentrations in association with wind from the northeast regions. The results here might indicate an effect of regional transport from southern, heavily polluted regions on atmospheric aerosols at regional background sites of the NCP in all seasons and that northern transport might also partially contribute in summer.

As shown in Fig. 2, we also investigated the effects of $\mathrm{RH}$ on the secondary aerosols. When RH was $<80 \%$, SIAs (especially nitrate) increased significantly as RH increased in autumn and winter, suggesting a significant effect of aqueous-phase reactions on SIA formation. Previous studies in urban Beijing show a successive increase in SIA with increased RH (Li et al., 2019b; Liu et al., 2016), suggesting that aqueous-phase processing affects nitrate formation in urban atmospheres. The wind speed also increased rapidly as RH increased from $60 \%$ to $80 \%$ and then maintained a high level in autumn in Xinglong, while it has been found to continually decrease with increased $\mathrm{RH}$ at urban sites of the NCP (Huang et al., 2019; Li et al., 2019b). This behavior further indicates regional transport has more of an influence on the SIA concentration in the background atmosphere than in the urban atmosphere over the NCP in autumn. In spring,
SIA only increased significantly at moderate RH levels as RH increased $(<60 \%)$, suggesting a weaker impact of aqueousphase processing on SIA formation in spring than in autumn and winter. When RH was $>60 \%$, the SIA concentrations decreased rapidly, which would be mainly due to insufficient samples $(n<30)$ with humidity above $60 \%$. Notably, the $\mathrm{OA}$ and sulfate concentrations were high even when RH was low $(\mathrm{RH}<40)$ in summer, which was significantly different from what occurred in other seasons, suggesting the important role of photochemistry in the formation of sulfate and OOA. Furthermore, OA did not increase as RH increased in summer, suggesting different formation mechanisms of OA in summer than in other seasons, which is specifically investigated in Sect. 3.4.

\subsubsection{Seasonality of the size distribution of the chemical components of $\mathbf{P M}_{1}$}

The size distribution of all $\mathrm{PM}_{1}$ species in each season was concentrated in accumulation mode (Fig. 3), with a peak diameter at approximately $600-800 \mathrm{~nm}$ (vacuum aerodynamic diameters, $d_{\mathrm{va}}$ ), indicating aerosols in the background atmosphere were highly aged and internally mixed (Jimenez et al., 2003). Compared to Beijing, OA in Xinglong had a larger peak diameter and a wider size distribution in each season (Hu et al., 2017). Compared to SIA, OA always had a higher concentration in the small-size mode $(100-500 \mathrm{~nm})$ in urban areas, likely caused by the existence of strong POA emissions (Zhang et al., 2014a; Liu et al., 2016). However, in Xinglong, the peak diameters of OA were close to those of SIA in the four seasons, indicating OA was highly oxidized in Xinglong. 

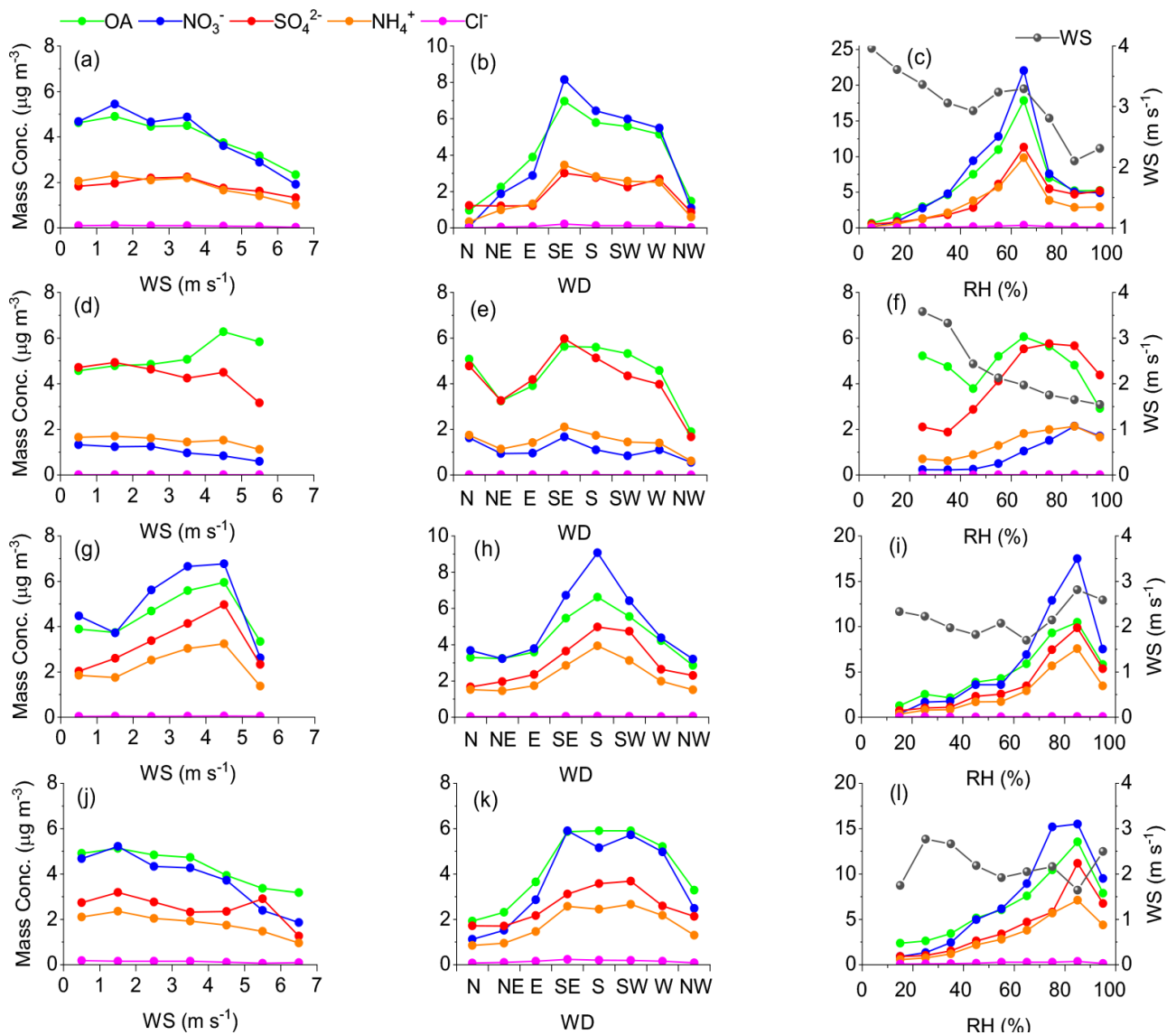

Figure 2. Variations in mass concentrations of $\mathrm{PM}_{1}$ species as functions of WS (wind speed), WD (wind direction) and RH in (a, b, c) spring, (d, e, f) summer, $(\mathbf{g}, \mathbf{h}, \mathbf{i})$ autumn and $(\mathbf{j}, \mathbf{k}, \mathbf{l})$ winter (OA: organic aerosol).
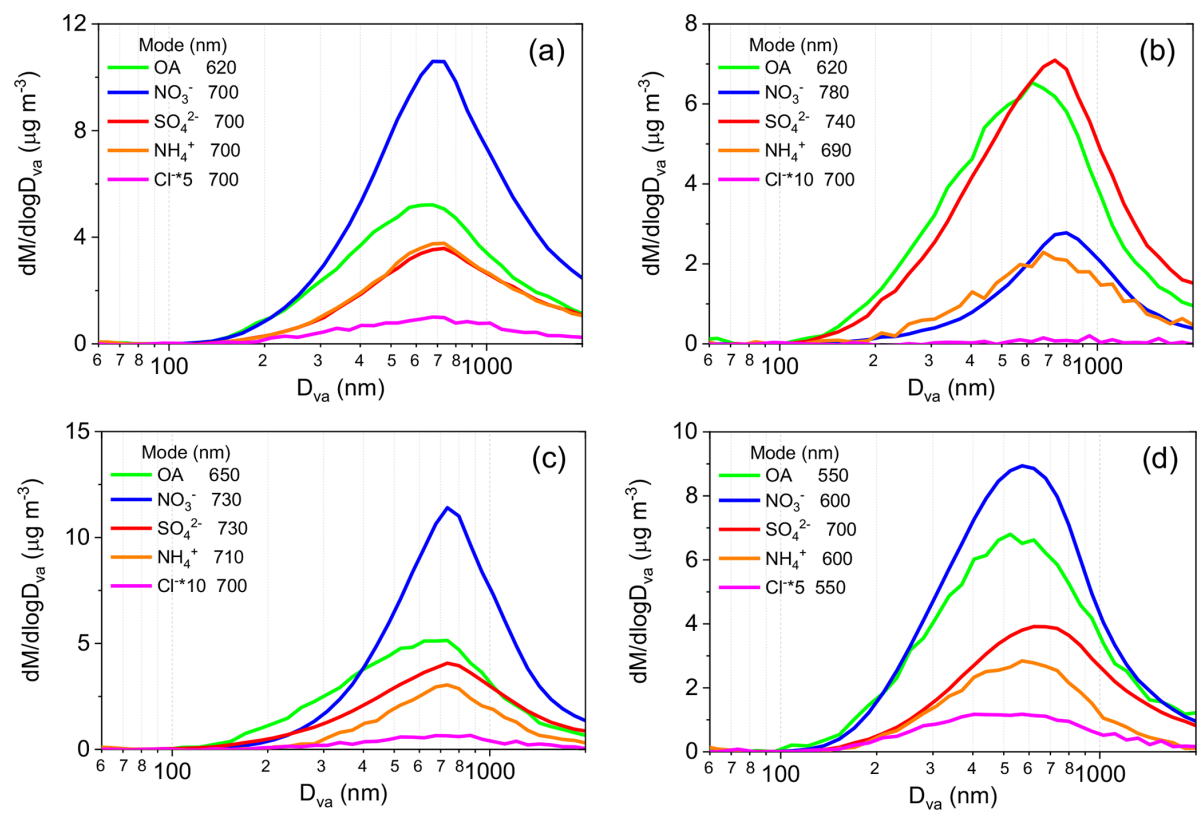

Figure 3. Mass size distributions of $\mathrm{PM}_{1}$ species in (a) spring, (b) summer, (c) autumn and (d) winter. 
The size distributions of SIA showed similar shapes in spring and autumn and peaked at approximately $700 \mathrm{~nm}$, suggesting internal mixing (Liu et al., 2016). The mode diameters of the SIA in Xinglong (700-750 nm) were higher than those in Beijing $(600-650 \mathrm{~nm})$ in spring and summer (Hu et al., 2017). The differences in SIA peak diameters may have been caused by the stronger photochemical activity and long-range transport in Xinglong than in Beijing in these two seasons. The peak diameter of sulfate in summer was the highest in the four seasons, indicating that the sulfate was highly aged in summer in the NCP. The peak diameters (550$700 \mathrm{~nm}$ ) of $\mathrm{PM}_{1}$ species in winter were lower than those in the other three seasons, which might be attributable to the existence of relatively higher primary emissions in winter.

\subsection{OA source appointment}

Owing to the high fraction of OOA in OA, it is extremely difficult to separate POA from OOA in Xinglong using PMF analysis, because the POA factor is easily mixed with the OOA factor. For example, for spring, according to the PMF analysis (Figs. S2-S6), in the two- to four-factor solutions, POA factors were mixed with OOA factors because the POA-like profile contained a higher-than-expected contribution from $m / z$ 44. In the five-factor solution, a POA factor appeared, while OOA was over-split, some of which showed similar characteristics. The mass spectrum pattern of the POA factor (Fig. S4, factor 3) mainly consisted of hydrocarbon ions $\left(\mathrm{C}_{n} \mathrm{H}_{2 n+1}^{+}\right.$and $\left.\mathrm{C}_{n} \mathrm{H}_{2 n-1}^{+}\right)$, which are commonly related to combustion emissions (Zhang et al., 2015; Sun et al., 2013b). The mass profile of the POA factor had some similarity with that of HOA and coal combustion OA (CCOA) (Hu et al., 2017; Elser et al., 2016). The correlation coefficient between POA and $\mathrm{NO}_{x}$ was 0.58 , and that between POA and chloride was 0.78, in spring, suggesting a significant contribution of coal combustion and trafficrelated sources to the POA factor in Xinglong. Moreover, HOA and CCOA show remarkably similar mass spectrum patterns when $m / z$ is below 120 (Sun et al., 2016, 2018), which is sometimes difficult to be separated by PMF analysis, so FFOA can be considered a combined factor of HOA and CCOA (Sun et al., 2018). In this study, it was difficult to separate CCOA from HOA because of the low percentage of POA in OA. Therefore, the POA factor in spring could also be considered FFOA, which is a typical profile in Xinglong. In autumn, the solution of the PMF analysis was similar to that in spring. A POA factor appeared until the sevenfactor solution and OOA was over-split. The POA factor in autumn could also be considered FFOA. We constrained the FFOA profiles separated by the five-factor solution of PMF analysis in spring and the seven-factor solution in autumn to better separate FFOA from OOA in spring and autumn, respectively. As a result, three OA factors, including FFOA, LO-OOA and MO-OOA, were identified with ME-2 analysis in spring and autumn. In winter, the three-factor solution
(FFOA, LO-OOA and MO-OOA) from PMF analysis was good enough, so it was not necessary to use ME-2 analysis to separate POA from OOA. In summer, no POA factor appeared in the two- to nine-factor solutions of the PMF analysis, suggesting the faction of POA in OA in summer was too low to be identified. Therefore, the PMF analysis results of two OA factors (LO-OOA and MO-OOA) were used. The proportions of FFOA to OA were relatively low in the other three seasons (14\%-23\%), mainly because of the low anthropogenic emissions around Xinglong station. The concentrations of FFOA were higher at night than during the daytime during the four seasons, which was mainly due to the variations in the PBL. The lower PBL at night suppressed the diffusion of pollutants. Meanwhile, higher primary emissions, such as coal-burning emissions, at night than during the daytime, also partly contributed.

The high $f_{44}$ values were permanent in the mass spectrum of both LO-OOA and MO-OOA. The $f_{44}$ values for MOOOA and LO-OOA in the four seasons ranged from $16.3 \%$ to $23.5 \%$ and $8.1 \%$ to $13.8 \%$, respectively. The $f_{43}$ values for MO-OOA and LO-OOA ranged from $4.8 \%$ to $5.2 \%$ and $6.8 \%$ to $9.1 \%$, respectively. The $\mathrm{O} / \mathrm{C}$ ratios of the MO-OOA factors in the four seasons were $0.93,0.93,0.84$ and 0.83 , respectively - higher than those in the corresponding LOOOA $(0.69,0.58,0.67$ and 0.49$)$. In addition, the correlation coefficient between LO-OOA and nitrate (sulfate) was $0.79(0.58)$ in autumn and $0.71(0.44)$ in winter. Therefore, LO-OOA correlated well with nitrate in autumn and winter. MO-OOA, meanwhile, correlated well with both nitrate and sulfate in autumn (MO-OOA vs. nitrate: 0.86; MO-OOA vs. sulfate: 0.87 ) and winter (MO-OOA vs. nitrate: 0.79; MOOOA vs. sulfate: 0.72 ), similar to the findings of previous studies in wintertime in Beijing (Hu et al., 2017). In comparison, LO-OOA had a low correlation coefficient with nitrate or sulfate, and MO-OOA had a correlation coefficient of 0.65 with sulfate, in summer. The poor correlation between LOOOA and secondary inorganic species has also been found in a previous study (Sun et al., 2018).

OOA accounted for as much as $77 \%-100 \%$ of the OA in the four seasons (Fig. 4). The percentages of OOA in OA during all seasons in Xinglong were much higher than those in urban Beijing (48\%-68\%; Hu et al., 2017), slightly higher than the results observed at national background stations in Waliguan (75\%; Zhang et al., 2019) in western China and at Lake Hongze in northern China (70\%; Zhu et al., 2016), and comparable to those observed in a less-polluted atmosphere in Hong Kong (80\%-85\%; Li et al., 2015) and a rural site in Xingzhou, central China (82\%; Wang et al., 2016). They were lower than those observed at a national background station at Mount Wuzhi in eastern China (100\%; Zhu et al., 2016). These characteristics indicate the occurrence of highly oxidized OA in Xinglong, which may be attributable to the high oxidizing ability and the strong impact of regional transportation in the background atmosphere of the NCP. 


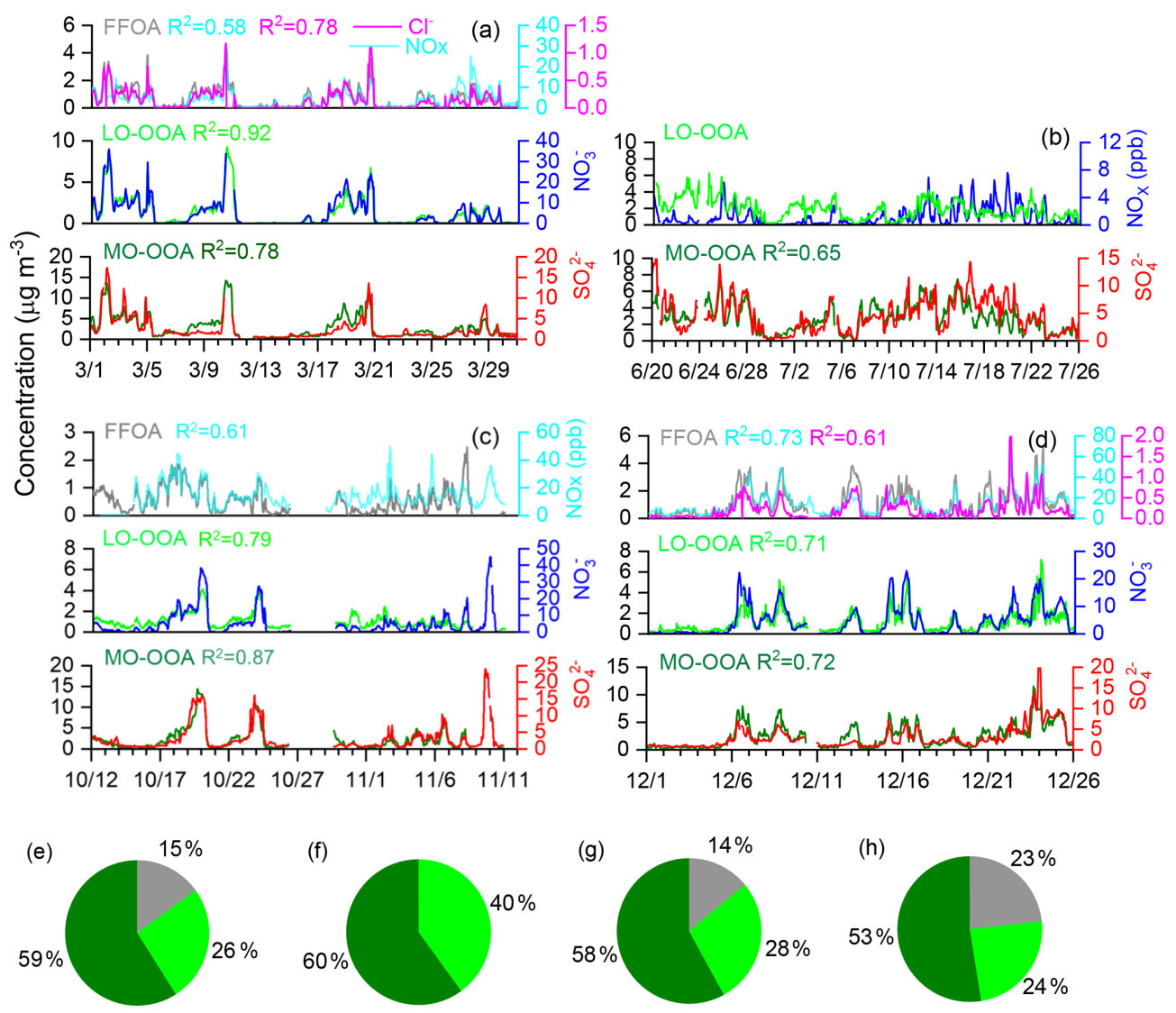

Figure 4. Time series of three OA factors in (a) spring, (b) summer, (c) autumn and (d) winter: FFOA, LO-OOA and MO-OOA. The time series of $\mathrm{NO}_{x}$, chloride, nitrate and sulfate are shown for comparison. The pie charts depict the average OA compositions in (e) spring, (f) summer, (g) autumn and (h) winter.

\subsection{Diurnal variations}

As shown in Fig. 5, nitrate exhibited drastic diurnal variation in each season, with a high concentration at night and low concentration during the daytime. This behavior was closely related to the variation in the PBL, temperature and $\mathrm{RH}$. The lower concentration of nitrate during the daytime can be attributed to the higher PBL and the evaporation of $\mathrm{NH}_{4} \mathrm{NO}_{3}$ due to the higher temperatures. In comparison, the higher concentration at night was closely related to lower temperature and higher $\mathrm{RH}$, which favor nitrate formation through heterogeneous reactions. Heterogeneous and aqueous-phase reactions and gas-to-particle condensation processes are the main pathways to forming fine-mode nitrate (Sun et al., 2018; Hu et al., 2017). High concentrations of $\mathrm{O}_{3}$ were observed during nighttime in the four seasons, which were about $45,70,35$ and $25 \mathrm{ppb}$, for spring, summer, autumn and winter, respectively. In addition, the $\mathrm{NO}_{2}$ concentrations ranged from 4 to $14 \mathrm{ppb}$ in all seasons. These results suggested the background atmosphere exhibited high atmospheric oxidation capacity, even at night, especially in summer, which indicated the hydrolysis of dinitrogen pentoxide $\left(\mathrm{N}_{2} \mathrm{O}_{5}\right)$ would contribute significantly to nitrate for- mation at night under high-RH conditions. In addition, the diurnal variation in nitrate showed an obvious increase from noon through the afternoon in each season, suggesting the increased nitrate concentrations were influenced by photochemical production (Fig. 5).

In comparison to the diurnal patterns of nitrate, sulfate showed flatter diurnal cycles in each season, identifying the regional characteristics of sulfate formation (Sun et al., 2016). In summer, sulfate increased rapidly from noon to evening, and the wind speed and $\mathrm{O}_{3}$ concentration increased significantly, indicating a strong influence of the regional transport of sulfate and $\mathrm{O}_{3}$ in summer. Specifically, the wind speed in autumn and winter increased slightly from 08:00 to 14:00 (all times are in Beijing standard time throughout the paper) from about 1.8 to $2.8 \mathrm{~m} \mathrm{~s}^{-1}$. However, in summer, the wind speed increased rapidly from 08:00 to 16:00 from 0.7 to $2.8 \mathrm{~m} \mathrm{~s}^{-1}$, and the $\mathrm{O}_{3}$ concentration increased significantly from 60 to $88 \mathrm{ppb}$, with an increase rate of $3.5 \mathrm{ppb} \mathrm{h}^{-1}$ at the same time. As a result, photochemical processing enhanced sulfate formation during the regional transport during the daytime. At night, however, the high sulfate concentration might be attributable to the lower PBL and enhance- 

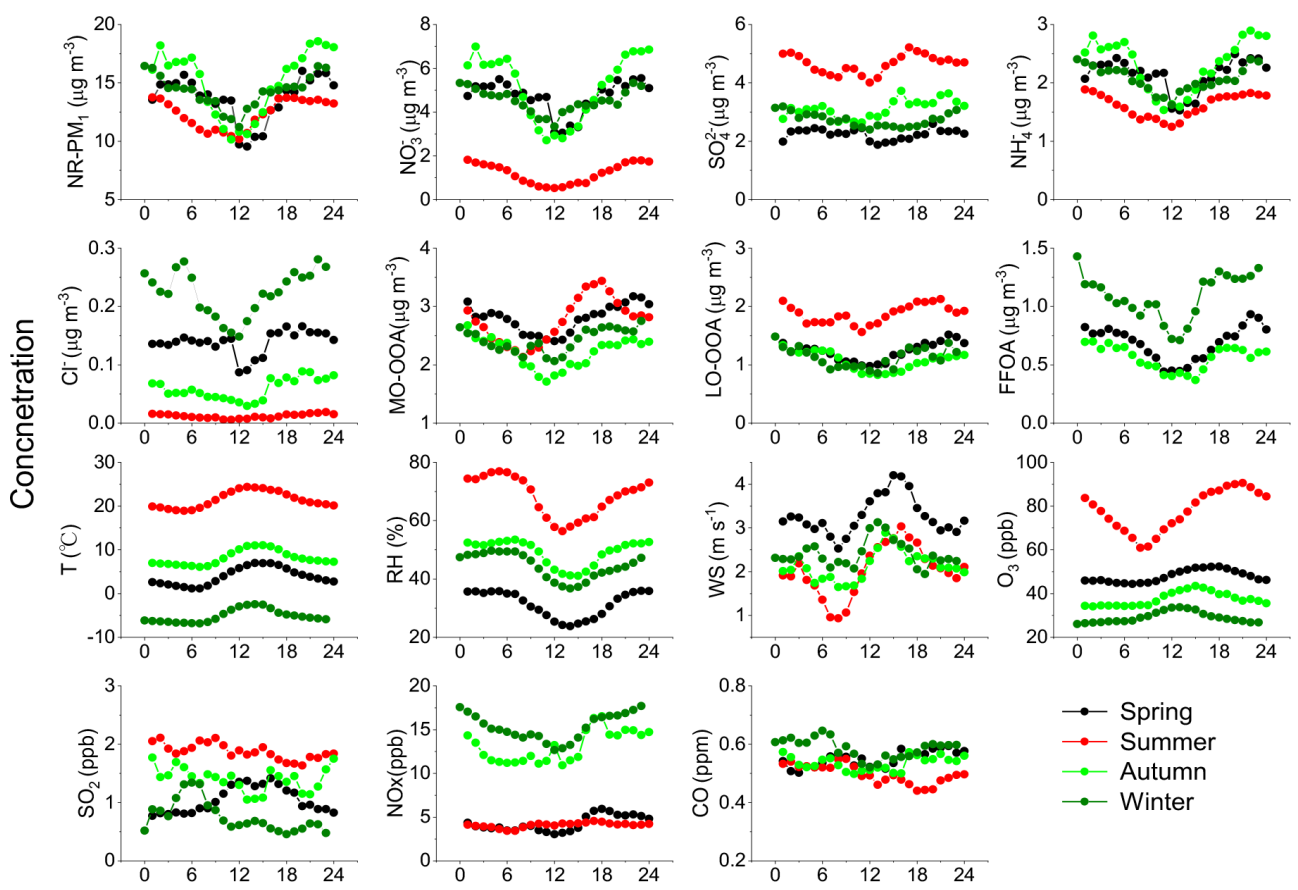

Hour of Day
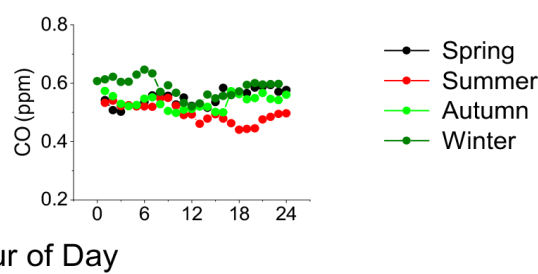

Figure 5. Diurnal variations in meteorological parameters, gaseous precursors and $\mathrm{PM}_{1}$ species in the four seasons.

ment of aqueous-phase processing under high temperatures and humidity (Zhang et al., 2014b).

MO-OOA exhibited similar drastic diurnal profiles in spring, autumn and winter, peaking in the afternoon and at night. The high concentration of MO-OOA at night was likely due to the co-effect of the low PBL and aqueous chemistry under high-RH conditions at night (Hu et al., 2017; Sun et al., 2018). Although the PBL expanded, the concentrations of MO-OOA increased significantly from 12:00 to 18:00, indicating an important role played by photochemical processes in MO-OOA production during the daytime in these three seasons. In summer, the concentration of MOOOA showed its greatest increase rate $\left(0.18 \mu \mathrm{g} \mathrm{m}^{-3} \mathrm{~h}^{-1}\right)$ from 09:00 to 18:00, implying stronger photochemical production of MO-OOA than in other seasons. Note that the wind speed in summer also increased rapidly from 09:00 to 16:00, along with the increase in MO-OOA, which may suggest regional transport also partly contributed to the rapid increase in MO-OOA during the daytime in summer. The diurnal profiles of LO-OOA in each season were flatter than those of MO-OOA. The decreased PBL mainly resulted in a higher concentration of LO-OOA at night. The increased concentration of LO-OOA from noon through the afternoon was mainly due to photochemical processes. The highest concentration of LO-OOA in summer suggested a stronger photochemical production of LO-OOA than in other seasons.

The primary components, chlorine and FFOA, exhibited similar diurnal variations, with the lowest concentrations in summer and highest concentrations in winter. Moreover, both chlorine and FFOA showed flat diurnal cycles in summer but dramatic diurnal cycles in winter, with high concentrations at night and low concentrations during the daytime. These characteristics could be attributed to the relatively high emissions in winter and the suppressed PBL at night.

\subsection{SOA chemistry and oxidation state}

\subsubsection{Oxidation state of $\mathrm{OA}$ and SOA}

As shown in Table 3, during the four seasons in this study, the average oxygen-to-carbon $(\mathrm{O} / \mathrm{C})$ and hydrogen-to-carbon $(\mathrm{H} / \mathrm{C})$ ratios, organic-mass-to-organic-carbon $(\mathrm{OM} / \mathrm{OC}) \mathrm{ra}-$ tios, and carbon oxidation state $(\mathrm{OSc})$ were in the ranges of $0.54-0.75,1.41-1.53,1.86-2.13$ and $-0.45-0.10$, respectively. The $\mathrm{O} / \mathrm{C}$ ratio was highest in summer $(0.75)$, second highest in spring $(0.71)$ and lowest in winter $(0.54)$. The high $\mathrm{O} / \mathrm{C}$ ratios in summer $(0.75)$ were also observed in urban Beijing and suburban areas of Hong Kong, indicating strong OOA formation via photochemical processing in summer. The low $\mathrm{O} / \mathrm{C}$ ratios in winter $(0.54)$ were related to a higher proportion of POA in OA than in other seasons. Mainly due to the weak influence of primary emissions, the $\mathrm{O} / \mathrm{C}$ ratios in Xinglong in all seasons (0.54-0.75) were slightly higher than those in urban Beijing (0.47-0.53), suggesting the high aging of the aerosols in Xinglong. Meanwhile, the O/C ratios in Xinglong in all seasons were much higher than those obtained at rural and suburban sites in China and in western countries, e.g., Hong Kong (0.38-0.52), Kaiping (0.47), 
Table 3. Elemental ratios and OSc (carbon oxidation state) in OA obtained from field observations at background-rural-suburban and urban sites. (O/C: oxygen-to-carbon ratio; $\mathrm{H} / \mathrm{C}$ : hydrogen-to-carbon ratio; OM/OC: organic-mass-to-organic-carbon ratio).

\begin{tabular}{|c|c|c|c|c|c|c|c|}
\hline Site & Site type & Period & $\mathrm{O} / \mathrm{C}$ & $\mathrm{H} / \mathrm{C}$ & $\mathrm{OM} / \mathrm{OC}$ & Osc & Reference \\
\hline \multirow[t]{4}{*}{ Xinglong (China) } & \multirow[t]{7}{*}{ Background } & Spring & 0.71 & 1.44 & 2.08 & -0.01 & \multirow[t]{4}{*}{ This study } \\
\hline & & Summer & 0.75 & 1.41 & 2.13 & 0.10 & \\
\hline & & Autumn & 0.61 & 1.47 & 1.94 & -0.26 & \\
\hline & & Winter & 0.54 & 1.53 & 1.86 & -0.45 & \\
\hline Lake Hongze (China) & & Spring & 0.67 & 1.52 & & -0.18 & Zhu et al. (2016) \\
\hline Mount Wuzhi (China) & & Spring & 0.98 & 1.32 & & 0.64 & Zhu et al. (2016) \\
\hline Waliguan (China) & & Summer & 0.99 & 1.43 & 2.44 & 0.55 & Zhang et al. (2019) \\
\hline \multirow[t]{4}{*}{ Hong Kong (China) } & \multirow[t]{8}{*}{ Rural-suburban } & Spring & 0.38 & 1.35 & 1.64 & -0.59 & \multirow[t]{4}{*}{ Li et al. (2015) } \\
\hline & & Summer & 0.52 & 1.36 & 1.84 & -0.32 & \\
\hline & & Autumn & 0.42 & 1.39 & 1.71 & -0.55 & \\
\hline & & Winter & 0.43 & 1.4 & 1.71 & -0.54 & \\
\hline Kaiping (China) & & Autumn & 0.47 & 1.48 & 1.77 & -0.54 & Huang et al. (2011) \\
\hline \multirow[t]{3}{*}{ Melpitz (Germany) } & & Summer & 0.52 & 1.51 & 1.83 & -0.47 & \multirow[t]{3}{*}{ Poulain et al. (2011) } \\
\hline & & Autumn & 0.54 & 1.48 & 1.84 & -0.4 & \\
\hline & & Winter & 0.53 & 1.48 & 1.83 & -0.41 & \\
\hline \multirow[t]{4}{*}{ Beijing (China) } & \multirow[t]{6}{*}{ Urban } & Spring & 0.49 & 1.63 & 1.81 & -0.64 & \multirow[t]{4}{*}{ Hu et al. (2017) } \\
\hline & & Summer & 0.53 & 1.61 & 1.88 & -0.54 & \\
\hline & & Autumn & 0.46 & 1.58 & 1.77 & -0.66 & \\
\hline & & Winter & 0.47 & 1.52 & 1.79 & -0.58 & \\
\hline Mexico City (Mexico) & & Spring & 0.53 & 1.82 & 1.73 & -0.77 & Aiken et al. (2009) \\
\hline Fresno, CA (US) & & Winter & 0.35 & 1.75 & 1.63 & -1.05 & Ge et al. (2012) \\
\hline
\end{tabular}

Fresno (0.35), Melpitz (0.52-0.54) and Mexico City (0.53) (Li et al., 2015; Huang et al., 2011; Poulain et al., 2011; Aiken et al., 2009; Ge et al., 2012; Hu et al., 2017), suggesting the OAs in Xinglong were highly aged. In addition, the $\mathrm{O} / \mathrm{C}$ ratios in Xinglong in the four seasons were comparable with those observed at the background Lake Hongze site in northern China. The slightly higher $\mathrm{O} / \mathrm{C}$ ratios of $\mathrm{OA}$ in national background areas in eastern and western China, such as 0.99 at Waliguan background station in summer and 0.98 at Mount Wuzhi site in spring (Zhang et al., 2019; Zhu et al., 2016), were due to the highly aged air mass during the long-range transport. Overall, the oxidation state of OA in Xinglong was far higher than that at urban, rural and suburban sites and comparable to that at background sites in eastern and western China.

Figure 6 compares the O/C ratios of OOA, LO-OOA and MO-OOA in a variety of environments grouped into two types according to their location: urban and suburban-ruralbackground sites. For some sites, only one OOA factor was identified, while for others, two OOA factors, including LOOOA and MO-OOA, were identified according to the different oxidation states. For the latter sites, the average O/C ratios of OOA can be reconstructed as a mass-weighted average of the $\mathrm{O} / \mathrm{C}$ ratios of LO-OOA and MO-OOA, according to $\mathrm{Ng}$ et al. (2010). The $\mathrm{O} / \mathrm{C}$ ratios of OOA at Xinglong in the four seasons (0.8-0.93) were comparable with those observed at the background Lake Hongze site (0.89) in northern China but lower than those observed in national background areas in eastern and western China, which was due to the highly aged air mass during the long-range transport in national background areas. These results highlight the high atmospheric oxidizing capacity in background areas in both southern and northern China. The $\mathrm{O} / \mathrm{C}$ ratios of OOA in Xinglong were far higher than those obtained at urban sites in lightly polluted areas, e.g., Hong Kong and Fresno, and those in suburban-rural-downwind areas, e.g., Jiaxing, Kaiping and Hong Kong. They were comparable to those in urban Beijing in the NCP in the four seasons (Li et al., 2015; 


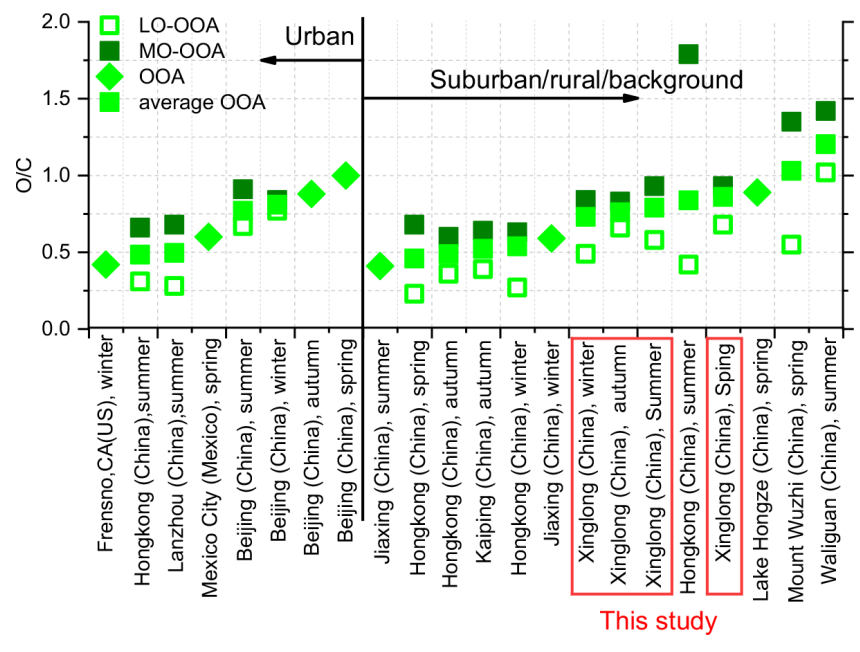

Figure 6. Estimated $\mathrm{O} / \mathrm{C}$ ratios of OOA, LO-OOA and MO-OOA at each site. The mass-weighted average OOA component is also shown for sites in which LO-OOA and MO-OOA are both resolved. (note MO-OOA and LO-OOA are identified as LV-OOA and SVOOA, respectively.)

Huang et al., 2011; Ge et al., 2012; Huang et al., 2013; Hu et al., 2017; Xu et al., 2014). The comparable O/C ratios of the OOA in Xinglong and Beijing (Hu et al., 2017) in winter were probably due to the relatively higher proportion of POA in the OA than in the other seasons. Although the $\mathrm{O} / \mathrm{C}$ ratios of OOA in Xinglong and Beijing were comparable and both at high levels, the formation mechanisms of OOA were distinct at the two sites, and a detailed discussion is provided in Sect. 3.4.2.

\subsubsection{Evolution and formation of SOA}

Figures 7 and 8 show the mass concentrations and fractions of LO-OOA and MO-OOA as functions of RH and odd oxygen $\left(\mathrm{O}_{x}=\mathrm{O}_{3}+\mathrm{NO}_{2}\right)$ in all seasons, respectively. Both LOOOA and MO-OOA increased significantly as RH increased when RH was $<90 \%$ in autumn and winter. Meanwhile, both of LO-OOA and MO-OOA increased significantly as LWC increased when LWC was below 160 and $140 \mu \mathrm{g} \mathrm{m}^{-3}$ in autumn and winter, respectively (Fig. S21). These behaviors suggested aqueous-phase processing had a significant influence on OOA formation in these two seasons. MO-OOA increased more rapidly than LO-OOA as RH increased. As a result, the mass fractions of MO-OOA increased by $25 \%$ in autumn and by $12 \%$ in winter when RH increased from $20 \%$ to $90 \%$. Correspondingly, the mass fraction of LOOOA decreased by $15 \%$ in autumn. These characteristics indicated that aqueous-phase processing plays a more important role in MO-OOA formation than that in LO-OOA in these two seasons. Note that the mass fraction of MO-OOA did not increase as $\mathrm{O}_{x}$ increased in winter, while it increased from $30 \%$ to $40 \%$ as RH increased from $30 \%$ to $90 \%$.
This characteristic suggested a more dominant important role of aqueous-phase processing on SOA formation than photochemical processing in this season. In addition, in autumn, the increases in LO-OOA and MO-OOA under high-RH conditions $(70 \%<\mathrm{RH}<90 \%)$ were associated with a significant increase in average wind speed from 1.8 to $2.9 \mathrm{~m} \mathrm{~s}^{-1}$ (Fig. 7k), which facilitated the transport of water vapor and pollutants from the heavily polluted southern regions.

In spring, LO-OOA and MO-OOA only increased under moderate $\mathrm{RH}(\mathrm{RH}<70 \%)$ as $\mathrm{RH}$ increased. Notably, $\mathrm{O}_{x}$ also increased when $\mathrm{RH}$ was $<70 \%$ as $\mathrm{RH}$ increased. The LWC value in spring was far lower than those in the other three seasons. LO-OOA and MO-OOA only increased when LWC was below $30 \mu \mathrm{g} \mathrm{m}^{-3}$ and then decreased when LWC was above $30 \mu \mathrm{g} \mathrm{m}^{-3}$ (Fig. S21). This characteristic suggested the weaker effect of aqueous-phase processing on SOA formation in spring than in autumn and winter. $\mathrm{O}_{x}$ concentration in spring was as high as in the other three seasons. Meanwhile, LO-OOA and MO-OOA increased rapidly at moderate $\mathrm{O}_{x}$ levels when $\mathrm{O}_{x}$ changed from 50 to $70 \mathrm{ppb}$ and then remained unchanged at high $\mathrm{O}_{x}$ levels. RH stayed at low levels $(\mathrm{RH}<40 \%)$ as $\mathrm{O}_{x}$ increased, suggesting a more important role of photochemical processing on SOA formation than aqueous-phase processing in spring.

In summer, both LO-OOA and MO-OOA showed overall increasing trends as $\mathrm{O}_{x}$ increased, while $\mathrm{RH}$ showed a corresponding overall decreasing trend. This behavior indicates a strong influence of photochemical processing on both LO-OOA and MO-OOA production. LO-OOA concentration decreased significantly as LWC increased and maintained low concentration $\left(<1 \mu \mathrm{g} \mathrm{m}^{-3}\right)$ when LWC was above $40 \mu \mathrm{g} \mathrm{m}^{-3}$. Meanwhile, LO-OOA showed a continuously decreasing trend as RH increased in summer, except for a slightly increasing trend when RH increased from $40 \%$ to $60 \%$, indicating photochemical-processingdominated LO-OOA formation. MO-OOA increased significantly with $\mathrm{O}_{x}$, while it increased slightly with RH $(40 \%<$ $\mathrm{RH}<60 \%$ ) first and then decreased with RH when RH was above $60 \%$. This characteristic suggested photochemicalprocessing-dominated MO-OOA formation, but the role of aqueous-phase processing under moderate RH $(40 \%<$ $\mathrm{RH}<60 \%$ ) conditions cannot be ruled out in summer in the background atmosphere. In comparison, previous studies found that aqueous-phase processing dominated MO-OOA formation in urban Beijing in summer (Xu et al., 2017; Duan et al., 2020). This difference of MO-OOA formation between urban and background sites in the NCP was mainly due to the higher atmospheric oxidation capability in the background atmosphere than in the urban atmosphere in summer. A previous study showed that $\mathrm{O}_{x}$ concentration at the background sites was $30 \%$ higher than that at the urban site during summertime (Wang et al., 2013). Furthermore, increases in LOOOA and MO-OOA as functions of $\mathrm{O}_{x}$ were clearly associated with the increases in wind speed in Xinglong, which were more significant in summer than in other seasons. In 

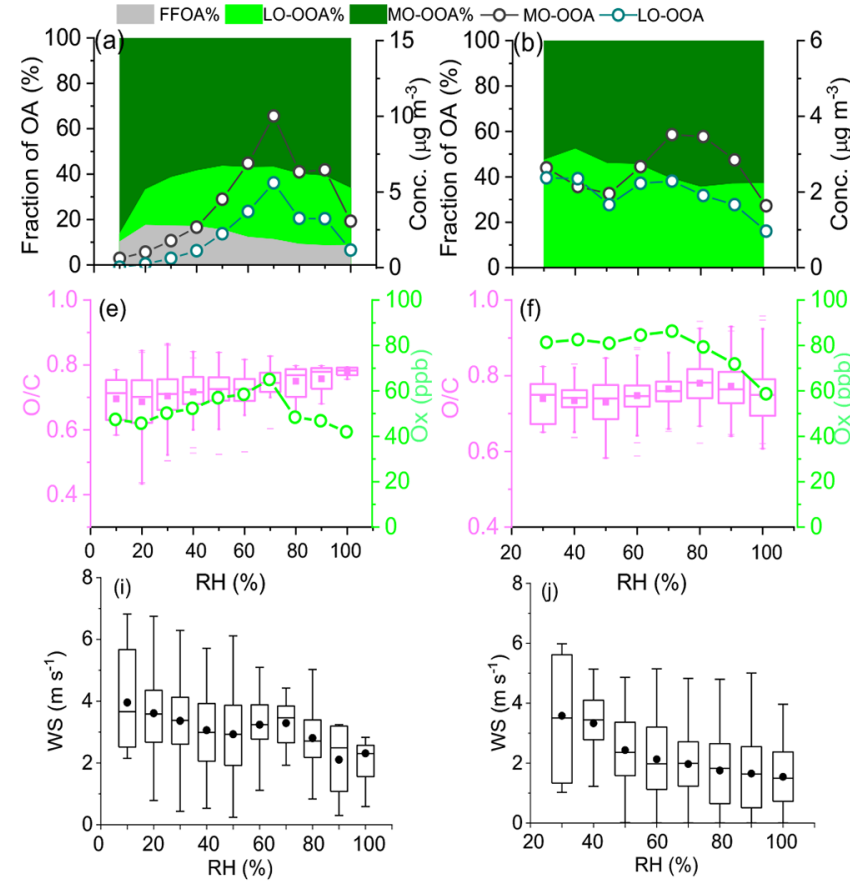
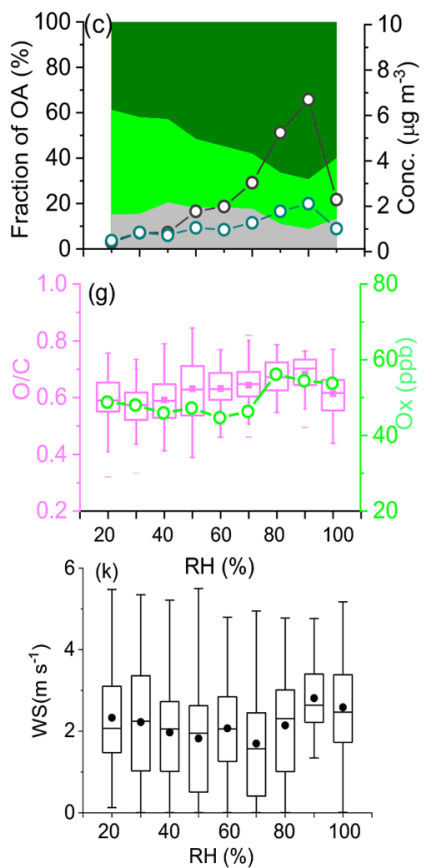
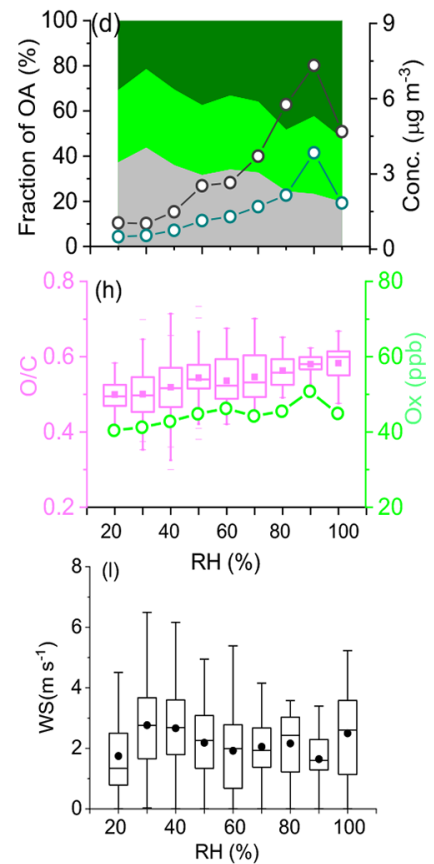

Figure 7. Variations in the mass concentrations of FFOA, LO-OOA and MO-OOA and the fractions of OA factors in OA, O/C, $\mathrm{O}_{x}$ (odd oxygen, $\mathrm{O}_{3}+\mathrm{NO}_{2}$ ) and WS (wind speed) as a function of $\mathrm{RH}$ in (a, e, i) spring, (b, f, j) summer, (c, $\left.\mathbf{g}, \mathbf{k}\right)$ autumn and (d, h, l) winter. The data were binned according to the RH (10\% increments).
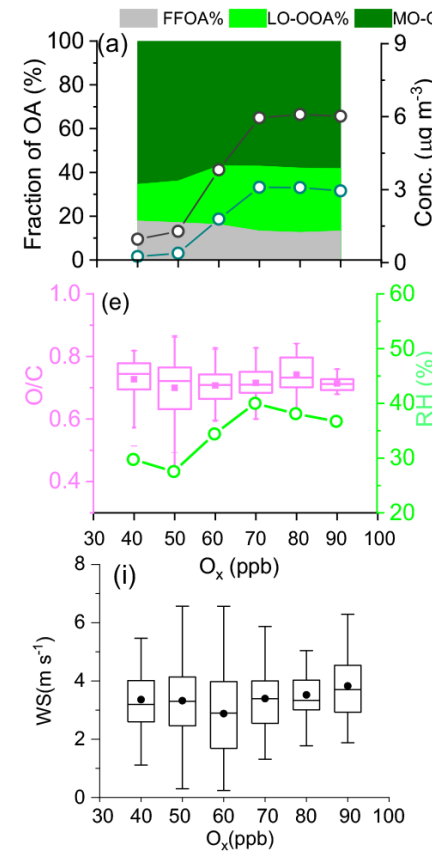
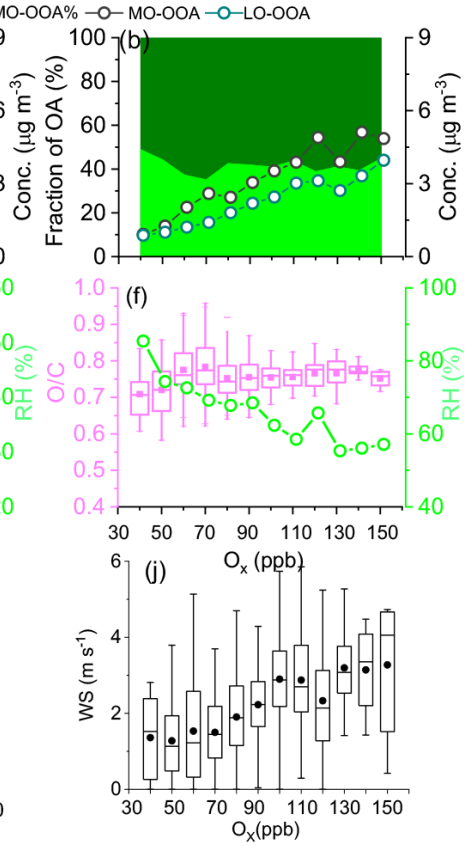
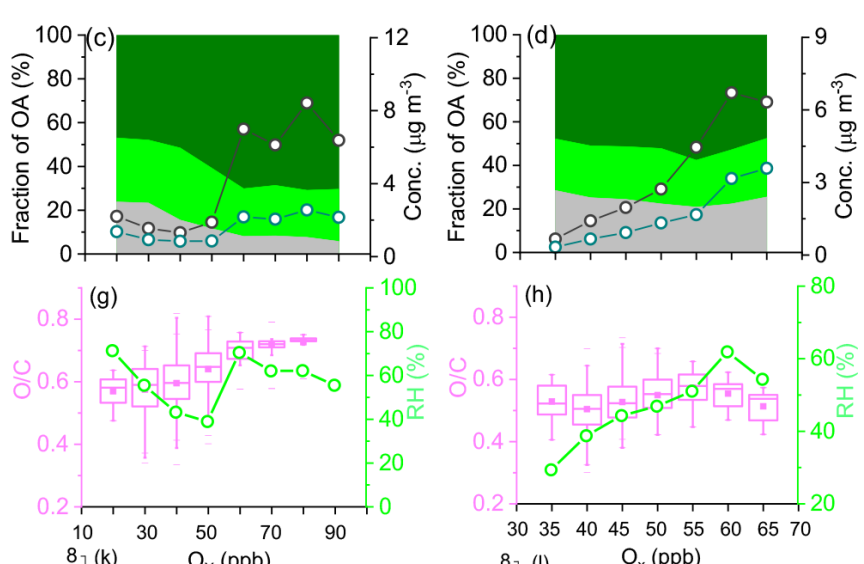

8 (l) $\quad \mathrm{O}_{\mathrm{x}}(\mathrm{ppb})$
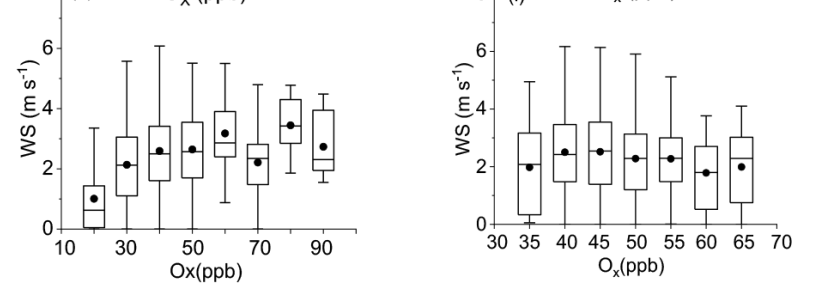

Figure 8. Variations in the mass concentrations of FFOA, LO-OOA and MO-OOA and the fractions of OA factors in OA, RH and WS (wind speed) as a function of $\mathrm{O}_{x}$ (odd oxygen, $\mathrm{O}_{3}+\mathrm{NO}_{2}$ ) in $(\mathbf{a}, \mathbf{e}, \mathbf{i})$ spring, $(\mathbf{b}, \mathbf{f}, \mathbf{j})$ summer, $(\mathbf{c}, \mathbf{g}, \mathbf{k})$ autumn and $(\mathbf{d}, \mathbf{h}, \mathbf{l})$ winter. The data were binned according to the $\mathrm{O}_{x}$ (10 ppb increments in spring, summer and autumn; 5 ppb increments in winter). 
comparison, in urban areas, such as Beijing, increases in LO-OOA were associated with the decreases in wind speed, which facilitated the accumulation of air pollutants $(\mathrm{Xu}$ et al., 2017). Such a difference between urban and background areas may be due to the influence of regional transport on the $\mathrm{O}_{x}$ and SOA concentrations in background areas. The continuous increases in SOA concentrations associated with the increases in wind speed in the background atmosphere may imply an important role of regional transport in SOA formation in summer. Different variations in the $\mathrm{O} / \mathrm{C}$ ratios of OA were observed in the four seasons. Clear increases in the $\mathrm{O} / \mathrm{C}$ ratios of $\mathrm{OA}$ as $\mathrm{RH}$ increased were observed in all seasons except summer, suggesting an impact of aqueous-phase processing on the oxidation state of $\mathrm{OA}$ in spring, autumn and winter.

\subsection{Transportation pathways}

To explore the transportation pathways and the effects of regional and long-distance transport on fine particles at the background site in the NCP, we calculated the backward trajectories of $\mathrm{PM}_{1}$ species with TrajStat and the HYSPLIT-4.8 model in four seasons. Both long-distance transport and regional air masses influenced Xinglong (Fig. 9). Based on the distances over which the air masses were transported, the clusters during the four seasons were defined as short, medium and long transportation pathways. Specifically, clusters 2 in spring, 2 in summer, 4 in autumn and 2 in winter were defined as short transportation pathways. Clusters 3 in spring; clusters 1, 3, 4 and 5 in summer; clusters 1 and 3 in autumn; and cluster 3 in winter were considered medium transportation pathways. Cluster 2 in spring, cluster 5 in summer, cluster 2 in autumn and cluster 1 in winter were considered long transportation pathways.

The short-distance trajectories originated in the southwestsoutheast of Xinglong - areas that suffer from serious pollution. The southwest trajectories started in southern Hebei Province and passed over Beijing. The southeast trajectories started at the Bohai Sea and extended through Tianjin and Tangshan. Although the three short-distance clusters accounted for only $27 \%-43 \%$ of all the air masses during each season, the $\mathrm{PM}_{1}$ concentrations for the short-distance clusters from the southern regions were the highest of all the clusters, indicating that aerosol particles at Xinglong station were greatly affected by the regional transport from southern regions. The long-distance trajectories mainly came from the farther northwest regions of Xinglong. The long-distance clusters accounted for $26 \%-49 \%$ of all the clusters in spring, autumn and winter. The long-distance clusters brought lesspolluted aerosols from the northern regions. These results were also supported by the low $\mathrm{PM}_{1}$ concentrations of 3.6$5.4 \mu \mathrm{g} \mathrm{m}^{-3}$ associated with the long-distance trajectories.

The air masses from the southern regions (clusters 2 and 3) dominated in summer and accounted for $56 \%$ of all the air masses, which was obviously higher than the percentages in other seasons $(27 \%-38 \%)$. Cluster 3 in summer started at Bohai Bay and passed through the Shandong Peninsula and over Bohai Bay. The $\mathrm{PM}_{1}$ concentrations for clusters 2 $\left(14.7 \mu \mathrm{g} \mathrm{m}^{-3}\right)$ and $3\left(12.2 \mu \mathrm{g} \mathrm{m}^{-3}\right)$ were both high. These results suggest a dominant role played by southern transport in submicron aerosol concentrations over the NCP in summer. Furthermore, the transport distances of clusters from the north and west regions in summer were shorter than those in other seasons. In general, with a decrease in the transport distance of clusters from the north and west regions, particle concentrations gradually increase (Hu et al., 2017). Although the clusters from these regions in summer only accounted for $15 \%$ and $8 \%$ of all the air masses, respectively, the $\mathrm{PM}_{1}$ concentrations for the two clusters (cluster 1: $12.8 \mathrm{\mu g} \mathrm{m}^{-3}$; cluster 5: $10.2 \mu \mathrm{g} \mathrm{m}^{-3}$ ) were both at high levels and similar to those associated with the southern air masses (cluster 2: $14.7 \mu \mathrm{g} \mathrm{m}^{-3}$ and cluster 3: $12.2 \mu \mathrm{g} \mathrm{m}^{-3}$ ). All these characteristics suggest that regional transport from Inner Mongolia (west and north regions of Xinglong) also partially contributes to the particle pollution in the background area of the NCP in summer.

\section{Conclusion}

The chemical components in $\mathrm{PM}_{1}$ were investigated during all four seasons at a background station in the NCP using a HR-ToF-AMS measurement. The average mass concentrations of NR-PM ${ }_{1}$ in the four seasons of spring, summer, autumn and winter were $13.7 \pm 16.0,12.4 \pm 7.4,15.1 \pm 18.7$ and $14.1 \pm 13.3 \mu \mathrm{g} \mathrm{m}^{-3}$, respectively. OA contributed the most to $\mathrm{PM}_{1}$ in summer, accounting for $40 \%$ by mass. Nitrate was the greatest SIA component in spring (34\%), winter $(31 \%)$ and autumn (34\%), while sulfate was the highest SIA component in summer $(38 \%) . \mathrm{PM}_{1}$ in Xinglong showed moderate acidity in spring, autumn and winter, with average $\mathrm{pH}$ values of $4.2 \pm 0.7,3.5 \pm 0.5$ and $3.7 \pm 0.6$, respectively, which were higher than those in the US and Europe. Excessive $\mathrm{NH}_{3}$ and high $\mathrm{NO}_{3} / \mathrm{SO}_{4}$ ratios contributed to the relatively lower aerosol acidity over the NCP in all seasons except in summer ( $\mathrm{pH}: 2.7 \pm 0.6$ ) on a regional scale. The size distribution of all $\mathrm{PM}_{1}$ species showed a consistent accumulation mode peaking at approximately $600-800 \mathrm{~nm}\left(d_{\mathrm{va}}\right)$, indicating a highly aged and internally mixed nature of the background aerosols.

The PMF and ME-2 methods were used to analyze the mass spectrum in Xinglong in the four seasons and identified three OA factors, including FFOA, LO-OOA and MOOOA. SOA (LO-OOA + MO-OOA) dominated OA as much as $77 \%-100 \%$ in the four seasons, especially in summer $(100 \%)$. The oxidation state and the process of evolution of OAs in the four seasons were further investigated, and an enhanced carbon oxidation state $(-0.45-0.10)$ and $\mathrm{O} / \mathrm{C}(0.54-$ $0.75)$ and OM/OC (1.86-2.13) ratios, compared with urban studies, were observed, with the highest oxidation state appearing in summer, likely due to the relatively stronger pho- 

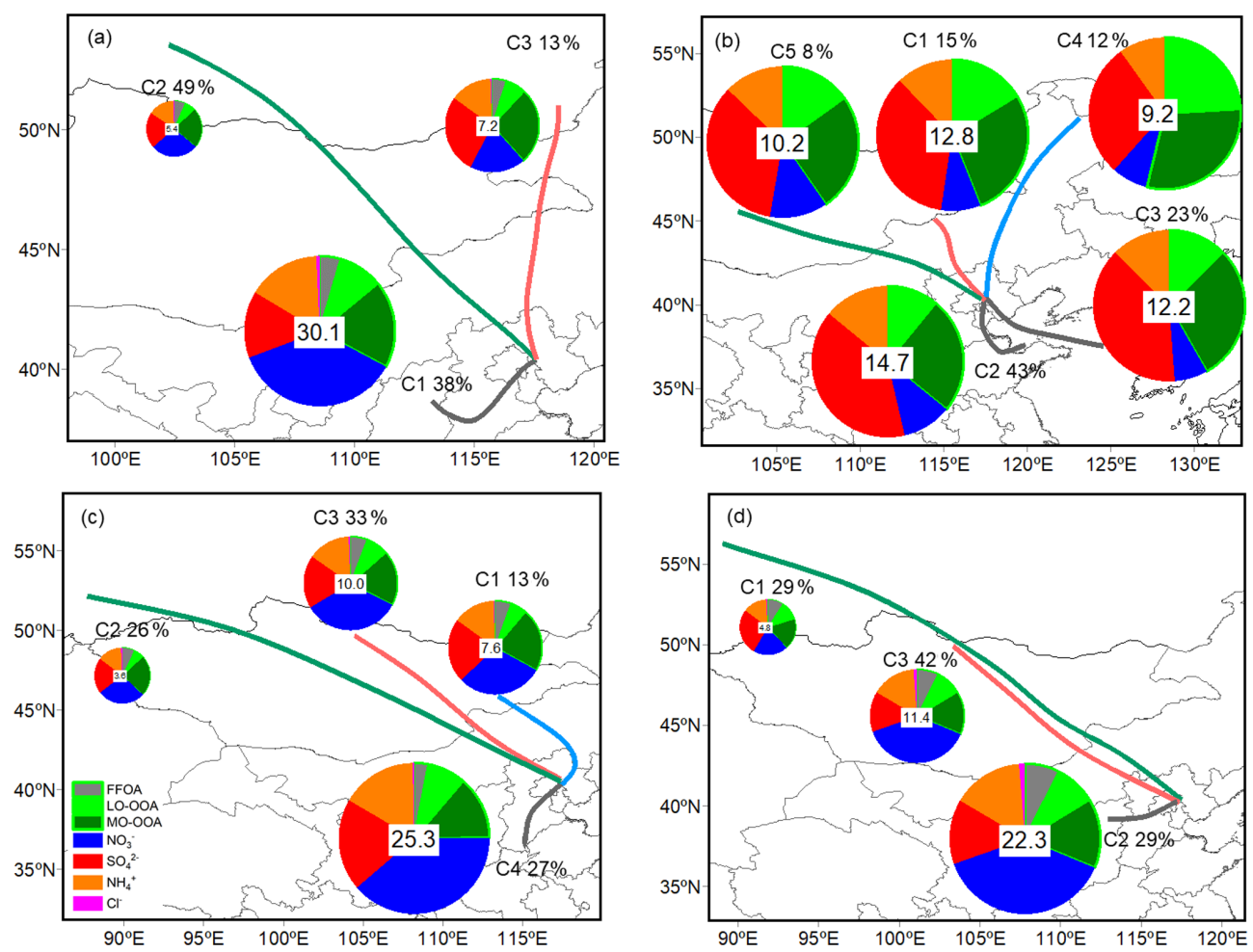

Figure 9. Average $48 \mathrm{~h}$ backward air mass trajectory clusters calculated at $1 \mathrm{~h}$ intervals in (a) spring, (b) summer, (c) autumn and (d) winter. The percentages of $\mathrm{PM}_{1}$ species in $\mathrm{PM}_{1}$ in each air mass trajectory cluster are shown in the pie charts with the average $\mathrm{PM}_{1}$ concentrations marked in the center of the pie charts.

tochemical processing that dominated the processes of both LO-OOA and MO-OOA formation. Aqueous-phase processing also contributed to the SOA formation and prevailed in winter, the role of which was more important in MOOOA than in LO-OOA. In addition, regional transport also played an important role in the variations in SOA. In particular in summer continuous increases in SOA concentration as a function of $\mathrm{O}_{x}$ were observed to be associated with the increases in wind speed. The backward trajectory analysis showed that higher $\mathrm{PM}_{1}$ concentrations were from the southern regions of Xinglong, with shorter transportation distances in all four seasons; whereas in summer, regional transport from Inner Mongolia (west and north regions of Xinglong) also partially contributed to the pollution over the NCP because of the similar $\mathrm{PM}_{1}$ concentrations to air masses from Inner Mongolia and southern regions of Xinglong.

Our results illustrate that the background particles over the $\mathrm{NCP}$ are influenced significantly by aging processes and regional transportation, which is similar to the situation for background aerosols over southern and western China. In addition, the high contribution of aerosol nitrate in the background NCP highlights how regional reductions in nitrogen oxide emissions are critical for remedying the occurrence of haze events over the NCP.
Data availability. The datasets can be accessed upon request to the corresponding authors.

Supplement. The supplement related to this article is available online at: https://doi.org/10.5194/acp-21-4521-2021-supplement.

Author contributions. LJ performed the research, designed the analysis approach and wrote the paper. LJ, LZ and HL had the original idea for the paper. LZ and HL provided writing guidance and revised the paper. LJ and CL calibrated the HR-ToF-AMS and performed data evaluation. CL provided ME-2 analysis guidance and the HR-ToF-AMS instrument. LJ and GW operated and maintained the HR-ToF-AMS instrument. All co-authors proofread and commented on the manuscript.

Competing interests. The authors declare that they have no conflict of interest.

Special issue statement. This article is part of the special issue "Multiphase chemistry of secondary aerosol formation under severe haze". It does not belong to a conference. 
Acknowledgements. This study was supported by the Ministry of Science and Technology of China (grant no. 2017YFC0210000), the Young Talent Project of the Center for Excellence in Regional Atmospheric Environment, CAS (CERAE202002), the National Natural Science Foundation of China (grant no. 41705110), the Beijing Municipal Natural Science Foundation (8192045), and Beijing Major Science and Technology Project (Z181100005418014). The authors are grateful for the support of the staff at Xinglong station.

Financial support. This research has been supported by the Ministry of Science and Technology of China (grant no. 2017YFC0210000), the Young Talent Project of the Center for Excellence in Regional Atmospheric Environment, CAS (grant no. CERAE202002), the National Natural Science Foundation of China (grant no. 41705110), the Beijing Municipal Natural Science Foundation (grant no. 8192045), and the Beijing Major Science and Technology Project (grant no. Z181100005418014).

Review statement. This paper was edited by Aijun Ding and reviewed by three anonymous referees.

\section{References}

Aiken, A. C., Salcedo, D., Cubison, M. J., Huffman, J. A., DeCarlo, P. F., Ulbrich, I. M., Docherty, K. S., Sueper, D., Kimmel, J. R., Worsnop, D. R., Trimborn, A., Northway, M., Stone, E. A., Schauer, J. J., Volkamer, R. M., Fortner, E., de Foy, B., Wang, J., Laskin, A., Shutthanandan, V., Zheng, J., Zhang, R., Gaffney, J., Marley, N. A., Paredes-Miranda, G., Arnott, W. P., Molina, L. T., Sosa, G., and Jimenez, J. L.: Mexico City aerosol analysis during MILAGRO using high resolution aerosol mass spectrometry at the urban supersite (T0) - Part 1: Fine particle composition and organic source apportionment, Atmos. Chem. Phys., 9, 6633-6653, https://doi.org/10.5194/acp-9-6633-2009, 2009.

Bougiatioti, A., Nikolaou, P., Stavroulas, I., Kouvarakis, G., Weber, R., Nenes, A., Kanakidou, M., and Mihalopoulos, N.: Particle water and $\mathrm{pH}$ in the eastern Mediterranean: source variability and implications for nutrient availability, Atmos. Chem. Phys., 16, 4579-4591, https://doi.org/10.5194/acp-16-4579-2016, 2016.

Canagaratna, M. R., Jimenez, J. L., Kroll, J. H., Chen, Q., Kessler, S. H., Massoli, P., Hildebrandt Ruiz, L., Fortner, E., Williams, L. R., Wilson, K. R., Surratt, J. D., Donahue, N. M., Jayne, J. T., and Worsnop, D. R.: Elemental ratio measurements of organic compounds using aerosol mass spectrometry: characterization, improved calibration, and implications, Atmos. Chem. Phys., 15, 253-272, https://doi.org/10.5194/acp-15-253-2015, 2015.

Canonaco, F., Crippa, M., Slowik, J. G., Baltensperger, U., and Prévôt, A. S. H.: SoFi, an IGOR-based interface for the efficient use of the generalized multilinear engine (ME2) for the source apportionment: ME-2 application to aerosol mass spectrometer data, Atmos. Meas. Tech., 6, 3649-3661, https://doi.org/10.5194/amt-6-3649-2013, 2013.

Ding, J., Zhao, P., Su, J., Dong, Q., Du, X., and Zhang, Y.: Aerosol $\mathrm{pH}$ and its driving factors in Beijing, Atmos. Chem. Phys., 19, 7939-7954, https://doi.org/10.5194/acp-19-7939-2019, 2019.
Du, W., Sun, Y. L., Xu, Y. S., Jiang, Q., Wang, Q. Q., Yang, W., Wang, F., Bai, Z. P., Zhao, X. D., and Yang, Y. C.: Chemical characterization of submicron aerosol and particle growth events at a national background site (3295 $\mathrm{m}$ a.s.1.) on the Tibetan Plateau, Atmos. Chem. Phys., 15, 10811-10824, https://doi.org/10.5194/acp-15-10811-2015, 2015.

Duan, J., Huang, R.-J., Lin, C., Dai, W., Wang, M., Gu, Y., Wang, Y., Zhong, H., Zheng, Y., Ni, H., Dusek, U., Chen, Y., Li, Y., Chen, Q., Worsnop, D. R., O'Dowd, C. D., and Cao, J.: Distinctions in source regions and formation mechanisms of secondary aerosol in Beijing from summer to winter, Atmos. Chem. Phys., 19, 10319-10334, https://doi.org/10.5194/acp-19-103192019, 2019.

Duan, J., Huang, R.-J., Li, Y., Chen, Q., Zheng, Y., Chen, Y., Lin, C., Ni, H., Wang, M., Ovadnevaite, J., Ceburnis, D., Chen, C., Worsnop, D. R., Hoffmann, T., O’Dowd, C., and Cao, J.: Summertime and wintertime atmospheric processes of secondary aerosol in Beijing, Atmos. Chem. Phys., 20, 3793-3807, https://doi.org/10.5194/acp-20-3793-2020, 2020.

Elser, M., Huang, R.-J., Wolf, R., Slowik, J. G., Wang, Q., Canonaco, F., Li, G., Bozzetti, C., Daellenbach, K. R., Huang, Y., Zhang, R., Li, Z., Cao, J., Baltensperger, U., El-Haddad, I., and Prévôt, A. S. H.: New insights into $\mathrm{PM}_{2.5}$ chemical composition and sources in two major cities in China during extreme haze events using aerosol mass spectrometry, Atmos. Chem. Phys., 16, 3207-3225, https://doi.org/10.5194/acp-16-3207-2016, 2016.

Ge, X., Setyan, A., Sun, Y., and Zhang, Q.: Primary and secondary organic aerosols in Fresno, California during wintertime: Results from high resolution aerosol mass spectrometry, J. Geophys. Res.-Atmos., 117, D19301, https://doi.org/10.1029/2012JD018026, 2012.

Guo, H., Xu, L., Bougiatioti, A., Cerully, K. M., Capps, S. L., Hite Jr., J. R., Carlton, A. G., Lee, S.-H., Bergin, M. H., Ng, N. L., Nenes, A., and Weber, R. J.: Fine-particle water and $\mathrm{pH}$ in the southeastern United States, Atmos. Chem. Phys., 15, 5211-5228, https://doi.org/10.5194/acp-15-5211-2015, 2015.

Guo, H., Weber, R. J., and Nenes, A.: High levels of ammonia do not raise fine particle $\mathrm{pH}$ sufficiently to yield nitrogen oxide-dominated sulfate production, Sci. Rep.-UK, 7, 12109, https://doi.org/10.1038/s41598-017-11704-0, 2017.

Hu, W., Hu, M., Hu, W.-W., Zheng, J., Chen, C., Wu, Y., and Guo, S.: Seasonal variations in high time-resolved chemical compositions, sources, and evolution of atmospheric submicron aerosols in the megacity Beijing, Atmos. Chem. Phys., 17, 9979-10000, https://doi.org/10.5194/acp-17-9979-2017, 2017.

Hu, X.-M., Ma, Z., Lin, W., Zhang, H., Hu, J., Wang, Y., Xu, X., Fuentes, J. D., and Xue, M.: Impact of the Loess Plateau on the atmospheric boundary layer structure and air quality in the North China Plain: A case study, Sci. Total Environ., 499, 228-237, https://doi.org/10.1016/j.scitotenv.2014.08.053, 2014.

Huang, R.-J., Wang, Y., Cao, J., Lin, C., Duan, J., Chen, Q., Li, Y., Gu, Y., Yan, J., Xu, W., Fröhlich, R., Canonaco, F., Bozzetti, C., Ovadnevaite, J., Ceburnis, D., Canagaratna, M. R., Jayne, J., Worsnop, D. R., El-Haddad, I., Prévôt, A. S. H., and O'Dowd, C. D.: Primary emissions versus secondary formation of fine particulate matter in the most polluted city (Shijiazhuang) in North China, Atmos. Chem. Phys., 19, 2283-2298, https://doi.org/10.5194/acp-19-2283-2019, 2019. 
Huang, X., Liu, Z., Liu, J., Hu, B., Wen, T., Tang, G., Zhang, J., Wu, F., Ji, D., Wang, L., and Wang, Y.: Chemical characterization and source identification of $\mathrm{PM}_{2.5}$ at multiple sites in the BeijingTianjin-Hebei region, China, Atmos. Chem. Phys., 17, 1294112962, https://doi.org/10.5194/acp-17-12941-2017, 2017.

Huang, X.-F., He, L.-Y., Hu, M., Canagaratna, M. R., Kroll, J. H., Ng, N. L., Zhang, Y.-H., Lin, Y., Xue, L., Sun, T.L., Liu, X.-G., Shao, M., Jayne, J. T., and Worsnop, D. R.: Characterization of submicron aerosols at a rural site in Pearl River Delta of China using an Aerodyne High-Resolution Aerosol Mass Spectrometer, Atmos. Chem. Phys., 11, 18651877, https://doi.org/10.5194/acp-11-1865-2011, 2011.

Huang, X.-F., Xue, L., Tian, X.-D., Shao, W.-W., Sun, T.-L., Gong, Z.-H., Ju, W.-W., Jiang, B., Hu, M., and He, L.-Y.: Highly timeresolved carbonaceous aerosol characterization in Yangtze River Delta of China: Composition, mixing state and secondary formation, Atmos. Environ., 64, 200-207, 2013.

Jimenez, J. L., Jayne, J. T., Shi, Q., Kolb, C. E., Worsnop, D. R., Yourshaw, I., Seinfeld, J. H., Flagan, R. C., Zhang, X., Smith, K. A., Morris, J. W., and Davidovits, P.: Ambient aerosol sampling using the Aerodyne Aerosol Mass Spectrometer, J. Geophys. Res., 108, 8425, https://doi.org/10.1029/2001jd001213, 2003.

Li, H., Zhang, Q., Zhang, Q., Chen, C., Wang, L., Wei, Z., Zhou, S., Parworth, C., Zheng, B., Canonaco, F., Prévôt, A. S. H., Chen, P., Zhang, H., Wallington, T. J., and He, K.: Wintertime aerosol chemistry and haze evolution in an extremely polluted city of the North China Plain: significant contribution from coal and biomass combustion, Atmos. Chem. Phys., 17, 4751-4768, https://doi.org/10.5194/acp-17-4751-2017, 2017.

Li, H., Cheng, J., Zhang, Q., Zheng, B., Zhang, Y., Zheng, G., and $\mathrm{He}, \mathrm{K} .:$ Rapid transition in winter aerosol composition in Beijing from 2014 to 2017: response to clean air actions, Atmos. Chem. Phys., 19, 11485-11499, https://doi.org/10.5194/acp-19-114852019, 2019a.

Li, J., Liu, Z., Cao, L., Gao, W., Yan, Y., Mao, J., Zhang, X., He, L., Xin, J., Tang, G., Ji, D., Hu, B., Wang, L., Wang, Y., Dai, L., Zhao, D., Du, W., and Wang, Y.: Highly time-resolved chemical characterization and implications of regional transport for submicron aerosols in the North China Plain, Sci. Total Environ., 705, 135803, https://doi.org/10.1016/j.scitotenv.2019.135803, 2019 b.

Li, J., Liu, Z., Gao, W., Tang, G., Hu, B., Ma, Z., and Wang, Y.: Insight into the formation and evolution of secondary organic aerosol in the megacity of Beijing, China, Atmos. Environ., 220, 117070, https://doi.org/10.1016/j.atmosenv.2019.117070, 2020.

Li, Y. J., Lee, B. Y. L., Yu, J. Z., Ng, N. L., and Chan, C. K.: Evaluating the degree of oxygenation of organic aerosol during foggy and hazy days in Hong Kong using high-resolution time-of-flight aerosol mass spectrometry (HR-ToF-AMS), Atmos. Chem. Phys., 13, 8739-8753, https://doi.org/10.5194/acp13-8739-2013, 2013.

Li, Y. J., Lee, B. P., Su, L., Fung, J. C. H., and Chan, C. K.: Seasonal characteristics of fine particulate matter (PM) based on highresolution time-of-flight aerosol mass spectrometric (HR-ToFAMS) measurements at the HKUST Supersite in Hong Kong, Atmos. Chem. Phys., 15, 37-53, https://doi.org/10.5194/acp-1537-2015, 2015.

Liu, M., Song, Y., Zhou, T., Xu, Z., Yan, C., Zheng, M., Wu, Z., $\mathrm{Hu}, \mathrm{M}$. , Wu, Y., and Zhu, T.: Fine particle pH during severe haze episodes in northern China, Geophys. Res. Lett., 44, 5213-5221, https://doi.org/10.1002/2017g1073210, 2017.

Liu, Z., Hu, B., Zhang, J., Yu, Y., and Wang, Y.: Characteristics of aerosol size distributions and chemical compositions during wintertime pollution episodes in Beijing, Atmos. Res., 168, 112, https://doi.org/10.1016/j.atmosres.2015.08.013, 2016.

Liu, Z., Gao, W., Yu, Y., Hu, B., Xin, J., Sun, Y., Wang, L., Wang, G., Bi, X., Zhang, G., Xu, H., Cong, Z., He, J., Xu, J., and Wang, Y.: Characteristics of $\mathrm{PM}_{2.5}$ mass concentrations and chemical species in urban and background areas of China: emerging results from the CARE-China network, Atmos. Chem. Phys., 18, 88498871, https://doi.org/10.5194/acp-18-8849-2018, 2018.

Middlebrook, A. M., Bahreini, R., Jimenez, J. L., and Canagaratna, M. R.: Evaluation of Composition-Dependent Collection Efficiencies for the Aerodyne Aerosol Mass Spectrometer using Field Data, Aerosol Sci. Technol., 46, 258-271, https://doi.org/10.1080/02786826.2011.620041, 2012.

Nah, T., Guo, H., Sullivan, A. P., Chen, Y., Tanner, D. J., Nenes, A., Russell, A., Ng, N. L., Huey, L. G., and Weber, R. J.: Characterization of aerosol composition, aerosol acidity, and organic acid partitioning at an agriculturally intensive rural southeastern US site, Atmos. Chem. Phys., 18, 11471-11491, https://doi.org/10.5194/acp-18-11471-2018, 2018.

Ng, N. L., Canagaratna, M. R., Zhang, Q., Jimenez, J. L., Tian, J., Ulbrich, I. M., Kroll, J. H., Docherty, K. S., Chhabra, P. S., Bahreini, R., Murphy, S. M., Seinfeld, J. H., Hildebrandt, L., Donahue, N. M., DeCarlo, P. F., Lanz, V. A., Prévôt, A. S. H., Dinar, E., Rudich, Y., and Worsnop, D. R.: Organic aerosol components observed in Northern Hemispheric datasets from Aerosol Mass Spectrometry, Atmos. Chem. Phys., 10, 46254641, https://doi.org/10.5194/acp-10-4625-2010, 2010.

Pan, Y., Wang, Y., Sun, Y., Tian, S., and Cheng, M.: Size-resolved aerosol trace elements at a rural mountainous site in Northern China: importance of regional transport, Sci. Total Environ., 461, 761-771, 2013.

Poulain, L., Spindler, G., Birmili, W., Plass-Dülmer, C., Wiedensohler, A., and Herrmann, H.: Seasonal and diurnal variations of particulate nitrate and organic matter at the IfT research station Melpitz, Atmos. Chem. Phys., 11, 12579-12599, https://doi.org/10.5194/acp-11-12579-2011, 2011.

Qin, Y. M., Li, Y. J., Wang, H., Lee, B. P. Y. L., Huang, D. D., and Chan, C. K.: Particulate matter (PM) episodes at a suburban site in Hong Kong: evolution of PM characteristics and role of photochemistry in secondary aerosol formation, Atmos. Chem. Phys., 16, 14131-14145, https://doi.org/10.5194/acp-16-141312016, 2016.

Seinfeld, J. H. and Pandis, S. N.: Atmospheric chemistry and physics: from air pollution to climate change, Wiley, NewYork, USA, 2016.

Song, S., Nenes, A., Gao, M., Zhang, Y., Liu, P., Shao, J., Ye, D., Xu, W., Lei, L., Sun, Y., Liu, B., Wang, S., and McElroy, M. B.: Thermodynamic Modeling Suggests Declines in Water Uptake and Acidity of Inorganic Aerosols in Beijing Winter Haze Events during 2014/2015-2018/2019, Environ. Sci. Tech. Lett., 6, 752760, https://doi.org/10.1021/acs.estlett.9b00621, 2019.

Sun, Y., Wang, Z., Fu, P., Jiang, Q., Yang, T., Li, J., and Ge, X.: The impact of relative humidity on aerosol composition and evolution processes during wintertime in Beijing, China, Atmos. Environ., 77, 927-934, 2013a. 
Sun, Y., Du, W., Fu, P., Wang, Q., Li, J., Ge, X., Zhang, Q., Zhu, C., Ren, L., Xu, W., Zhao, J., Han, T., Worsnop, D. R., and Wang, Z.: Primary and secondary aerosols in Beijing in winter: sources, variations and processes, Atmos. Chem. Phys., 16, 8309-8329, https://doi.org/10.5194/acp-16-8309-2016, 2016.

Sun, Y., Xu, W., Zhang, Q., Jiang, Q., Canonaco, F., Prévôt, A. S. H., Fu, P., Li, J., Jayne, J., Worsnop, D. R., and Wang, Z.: Source apportionment of organic aerosol from 2-year highly time-resolved measurements by an aerosol chemical speciation monitor in Beijing, China, Atmos. Chem. Phys., 18, 8469-8489, https://doi.org/10.5194/acp-18-8469-2018, 2018.

Sun, Y. L., Wang, Z. F., Fu, P. Q., Yang, T., Jiang, Q., Dong, H. B., Li, J., and Jia, J. J.: Aerosol composition, sources and processes during wintertime in Beijing, China, Atmos. Chem. Phys., 13, 4577-4592, https://doi.org/10.5194/acp-13-4577-2013, 2013 b.

Tan, T., Hu, M., Li, M., Guo, Q., Wu, Y., Fang, X., Gu, F., Wang, Y., and Wu, Z.: New insight into $\mathrm{PM}_{2.5}$ pollution patterns in Beijing based on one-year measurement of chemical compositions, Sci. Total Environ., 621, 734-743, https://doi.org/10.1016/j.scitotenv.2017.11.208, 2018.

Tao, M., Chen, L., Su, L., and Tao, J.: Satellite observation of regional haze pollution over the North China Plain, J. Geophys. Res.-Atmos., 117, D12203, https://doi.org/10.1029/2012JD017915, 2012.

Tian, S., Pan, Y., and Wang, Y.: Ion balance and acidity of sizesegregated particles during haze episodes in urban Beijing, Atmos. Res., 201, 159-167, 2018.

Ulbrich, I. M., Canagaratna, M. R., Zhang, Q., Worsnop, D. R., and Jimenez, J. L.: Interpretation of organic components from Positive Matrix Factorization of aerosol mass spectrometric data, Atmos. Chem. Phys., 9, 2891-2918, https://doi.org/10.5194/acp-92891-2009, 2009.

Wang, Q., Zhao, J., Du, W., Ana, G., Wang, Z., Sun, L., Wang, Y., Zhang, F., Li, Z., and Ye, X.: Characterization of submicron aerosols at a suburban site in central China, Atmos. Environ., 131, 115-123, 2016.

Wang, S., Wang, L., Li, Y., Wang, C., Wang, W., Yin, S., and Zhang, R.: Effect of ammonia on fine-particle $\mathrm{pH}$ in agricultural regions of China: comparison between urban and rural sites, Atmos. Chem. Phys., 20, 2719-2734, https://doi.org/10.5194/acp20-2719-2020, 2020.

Wang, Y., Hu, B., Tang, G., Ji, D., Zhang, H., Bai, J., Wang, X., and Wang, Y.: Characteristics of ozone and its precursors in Northern China: A comparative study of three sites, Atmos. Res., 132, 450-459, 2013.

Weber, R. J., Guo, H., Russell, A. G., and Nenes, A.: High aerosol acidity despite declining atmospheric sulfate concentrations over the past 15 years, Nat. Geosci., 9, 282-285, https://doi.org/10.1038/ngeo2665, 2016.

Xu, J., Zhang, Q., Chen, M., Ge, X., Ren, J., and Qin, D.: Chemical composition, sources, and processes of urban aerosols during summertime in northwest China: insights from high-resolution aerosol mass spectrometry, Atmos. Chem. Phys., 14, 1259312611, https://doi.org/10.5194/acp-14-12593-2014, 2014.

Xu, W., Han, T., Du, W., Wang, Q., Chen, C., Zhao, J., Zhang, Y., Li, J., Fu, P., Wang, Z., Worsnop, D. R., and Sun, Y.: Effects of Aqueous-Phase and Photochemical Processing on Secondary Organic Aerosol Formation and Evolu- tion in Beijing, China, Environ. Sci. Technol., 51, 762-770, https://doi.org/10.1021/acs.est.6b04498, 2017.

Xu, W., Sun, Y., Wang, Q., Zhao, J., Wang, J., Ge, X., Xie, C., Zhou, W., Du, W., Li, J., Fu, P., Wang, Z., Worsnop, D. R., and Coe, H.: Changes in Aerosol Chemistry From 2014 to 2016 in Winter in Beijing: Insights From High-Resolution Aerosol Mass Spectrometry, J. Geophys. Res.-Atmos., 124, 1132-1147, https://doi.org/10.1029/2018jd029245, 2019.

Yuan, Q., Li, W., Zhou, S., Yang, L., Chi, J., Sui, X., and Wang, W.: Integrated evaluation of aerosols during haze-fog episodes at one regional background site in North China Plain, Atmospheric Research, 156, 102-110, 10.1016/j.atmosres.2015.01.002, 2015.

Zhang, J., Wang, Y., Huang, X., Liu, Z., Ji, D., and Sun, Y.: Characterization of organic aerosols in Beijing using an aerodyne highresolution aerosol mass spectrometer, Adv. Atmos. Sci., 32, 877888, 2015.

Zhang, J. K., Sun, Y., Liu, Z. R., Ji, D. S., Hu, B., Liu, Q., and Wang, Y. S.: Characterization of submicron aerosols during a month of serious pollution in Beijing, 2013, Atmos. Chem. Phys., 14, 2887-2903, https://doi.org/10.5194/acp-14-2887-2014, 2014a.

Zhang, Q., Jimenez, J. L., Canagaratna, M. R., Ulbrich, I. M., Ng, N. L., Worsnop, D. R., and Sun, Y.: Understanding atmospheric organic aerosols via factor analysis of aerosol mass spectrometry: a review, Anal. Bioanal. Chem., 401, 3045-3067, https://doi.org/10.1007/s00216-011-5355-y, 2011.

Zhang, X., Xu, J., Kang, S., Zhang, Q., and Sun, J.: Chemical characterization and sources of submicron aerosols in the northeastern Qinghai-Tibet Plateau: insights from highresolution mass spectrometry, Atmos. Chem. Phys., 19, 78977911, https://doi.org/10.5194/acp-19-7897-2019, 2019.

Zhang, Y.: Characterization of sub-micron aerosol and its change processes in BIV (Beijing and its vicinity) region, $\mathrm{PhD}$ thesis, Meteorology, Chinese Academy of Meteorological Sciences, China Meteorological Administration, Beijing, 2011.

Zhang, Y. M., Zhang, X. Y., Sun, J. Y., Hu, G. Y., Shen, X. J., Wang, Y. Q., Wang, T. T., Wang, D. Z., and Zhao, Y.: Chemical composition and mass size distribution of $\mathrm{PM}_{1}$ at an elevated site in central east China, Atmos. Chem. Phys., 14, 12237-12249, https://doi.org/10.5194/acp-14-12237-2014, 2014b.

Zhang, Z., Zhang, Y., Zhang, X., Wang, Y., Shen, X., Sun, J., and Zhou, H.: Sources and characteristics of regional background $\mathrm{PM}_{1}$ in North China during the autumn and winter polluted period, Environ. Sci., 38, 2647-2655, 2017 (in Chinese).

Zhao, D., Xin, J., Gong, C., Quan, J., Liu, G., Zhao, W., Wang, Y., Liu, Z., and Song, T.: The formation mechanism of air pollution episodes in Beijing city: Insights into the measured feedback between aerosol radiative forcing and the atmospheric boundary layer stability, Sci. Total Environ., 692, 371-381, 2019.

Zhu, Q., He, L.-Y., Huang, X.-F., Cao, L.-M., Gong, Z.-H., Wang, C., Zhuang, X., and Hu, M.: Atmospheric aerosol compositions and sources at two national background sites in northern and southern China, Atmos. Chem. Phys., 16, 10283-10297, https://doi.org/10.5194/acp-16-10283-2016, 2016. 